\title{
Władze wojskowe, cywilne i kościelne a problem cerkwi prawosławnych w II Rzeczypospolitej - studium na przykładzie świątyń Suwałk, Łomży i Augustowa*
}

\begin{abstract}
Abstrakt: W artykule przedstawiono politykę władz wojskowych, cywilnych i kościelnych w okresie II Rzeczypospolitej w stosunku do cerkwi prawosławnych, wzniesionych za czasów zaboru rosyjskiego przede wszystkim z myślą o rosyjskim wojsku i administracji. Na przykładzie świątyń w Suwałkach, Augustowie i Łomży starano się sprecyzować pewne schematy postępowania z prawosławnym dziedzictwem (opuszczonym przez władze rosyjskie w trakcie I wojny światowej), charakterystyczne dla obszaru całego Królestwa Polskiego.
\end{abstract}

Słowa kluczowe: II Rzeczpospolita, mniejszości religijne, Kościół prawosławny, Suwałki, Łomża, Augustów.

Abstract: The article presents the policy of military, civil and Church authorities of the Second Polish Republic towards the Orthodox churches constructed in the Russian partition, mainly for Russian officials and army. An attempt was made to identify, on the example of Orthodox Church buildings at Suwałki, Augustów and Łomża, certain patterns of actions towards the Orthodox Church heritage (abandoned by the Russian authorities during World War I), characteristic of the whole Kingdom of Poland.

Keyw ords: Second Polish Republic, religious minorities, Orthodox Church, Suwałki, Łomża, Augustów.

\footnotetext{
* Artykuł powstał w ramach grantu wewnętrznego przyznanego przez Wydział Nauk Historycznych i Pedagogicznych Uniwersytetu Wrocławskiego na realizację projektu badawczego pt. Wtadze wojskowe II Rzeczypospolitej a problem cerkwi prawosławnych - studium na przyktadzie dawnych guberni suwalskiej i tomżyńskiej.
} 
Przygraniczne położenie guberni suwalskiej i łomżyńskiej spowodowało, że w chwili wypowiedzenia wojny Rosji przez Niemcy, znalazły się one w bezpośrednim zagrożeniu działaniami militarnymi. Ofensywa rosyjska, która w połowie sierpnia $1914 \mathrm{r}$. ruszyła w kierunku Prus Wschodnich, zakończyła się wielką klęską w okolicach wsi Tannenberg. Już dwa tygodnie później wojska niemieckie zajęły Suwałki, a następnie wkroczyły do Augustowa. W listopadzie przewagę odzyskali Rosjanie, docierając do Wielkich Jezior Mazurskich, jednak już w lutym 1915 r., w wyniku uderzenia w kierunku Grodna i Białegostoku, okupację niemiecką rozciagnnięto na większą część guberni suwalskiej i znaczący fragment łomżyńskiej (m.in. na Szczuczyn, Grajewo i Kolno). Sukcesu strony niemieckiej dopełniło uderzenie podjęte latem, skutkujące zajęciem przez Rzeszę całej północno-wschodniej części Królestwa Polskiego i przekroczeniem jego wschodniej granicy ${ }^{1}$.

Wycofujące się wojska rosyjskie ewakuowały ze sobą pracowników administracji carskiej oraz spora część ludności cywilnej niepowiązaną z aparatem biurokratycznym. Według badań Jarosława Szlaszyńskiego na Augustowszczyźnie liczba mieszkańców zmniejszyła się, jeszcze na skutek mobilizacji, o ponad $31 \%^{2}$. Pod niemiecki zarząd wojskowy, ustanowiony na okupowanych terenach, przejęto siedziby opuszczonych urzędów, obiekty użyteczności publicznej, jak i budynki koszarowe. W gestii nowych władz znalazły się także prawosławne świątynie - zarówno te służące dotychczas wojsku, jak i ludności cywilnej. Na łamach czasopisma „Варшавскій Епархіалный Листокь” nieznany autor pisał: „Во всњхъ мъстностяхъ, чрезъ которыя имъ [wojskom niemieckim - P.Z.] приходилось проходить, они намъренно подчеркивали свое злостно-кощунственное отношеніе къ православной святынъ, свидътельствуя тъмъ о своей низости душевной, о тупости своего деревяннаго сердца, неспособпаго подняться элементарнаго уваженія чужихь вьрованій"з.

Podczas pobytu wojsk niemieckich w Suwałkach we wrześniu 1914 r., sobór Zaśnięcia Najświętszej Maryi Panny przeznaczono na lazaret. Posługujący przy świątyni psalmista i starosta cerkiewny relacjonowali, że we wnętrzu rozrzucono słomę, na której ułożono rannych i przykryto ich cerkiewnymi dywanami. W różnych miejscach obiektu pozostawiono zakrwawioną bieliznę

\footnotetext{
${ }^{1} \mathrm{Na}$ temat I wojny światowej na opisywanym terenie zob. Materiaty $z$ konferencji naukowej Wielka Wojna. Suwalszczyzna i Zaniemenie 1914-1918 („Rocznik Augustowsko-Suwalski” 2014, t. XIV), m.in. artykuły: S. Czerep, Operacja mazursko-augustowska 1915 roku, s. 37-58; T. Radziwonowicz, Na tyłach frontu. O wojennej codzienności w guberni suwalskiej (1914-1915), s. 59-92; J. Szlaszyński, Augustów w poczqtkowym okresie pierwszej wojny światowej, s. 119-130.

2 J. Szlaszyński, Od pierwszej do drugiej wojny światowej, w: Augustów. Monografia historyczna, red. J. Szlaszyński, A. Makowski, Augustów 2007, s. 353.

${ }^{3}$ Оскверненія нглиами православныхь иерквей въ Сувалской губерніи, „Варшавскій Епархіалный Листокъ”, 1 XII 1914, № 23, s. 352.
} 
i niedopałki papierosów. W centralnej części ustawiono nocnik z fekaliami. W jednej z cerkwi wojskowych wyłamano wszystkie drzwi i urządzono stajnię końska. Zniszczone i rozgrabione zostały niektóre elementy wyposażenia, takie jak krzyże cerkiewne, korony ślubne, świeczniki. Ornaty przerobiono na czapraki dla koni. Prezbiterium pełniło najpewniej funkcję stołówki, o czym świadczyły znajdujące się tam butelki po winie ${ }^{4}$. W Augustowie splądrowano mieszkanie kleru parafialnego. Sobór św. Trójcy w Łomży znalazł się zaś, co najmniej dwukrotnie (w marcu i kwietniu 1915 r.), pod ostrzałem niemieckich samolotów. Te jednak, poza wybiciem części szyb i zasypaniem wnętrza gruzem, nie wyrządziły większych szkód ${ }^{5}$.

Przez cały okres okupacji niemieckiej w wymienionych, jak i innych cerkwiach na terenie Suwałk, Łomży i Augustowa, czy szerzej całego Królestwa Polskiego, nie odbywały się prawosławne nabożeństwa. Wiele obiektów było zamkniętych i nieużytkowanych, w części zachowano funkcje sakralne (z przeznaczeniem na kościoły garnizonowe - ewangelickie lub katolickie), pozostałe przemianowano na wojskowe składy i magazyny.

Po zakończeniu wojny ${ }^{6}$ i odrodzeniu państwa polskiego należało rozstrzygnąć, czy funkcje nadane świątyniom przez Niemców zostaną utrzymane oraz czy wznowi się działanie obiektów nieczynnych. Zdecydowana część głosów, zarówno jeśli chodzi o władze cywilne (centralne i samorządowe), wojskowe, jak i kościelne katolickie, odnosiła się do ich likwidacji. Prawosławnym cerkwiom odmawiano zazwyczaj przywileju sacrum, widząc w nich - przez wzgląd na prestiżową lokalizację w miejskiej przestrzeni oraz szatę architektoniczna właściwą dla świątyń wznoszonych na terenie imperium Romanowów - narzędzie polityki rusyfikacyjnej, a co za tym idzie niewygodny element krajobrazu urbanistycznego. W związu ze znaczacym spadkiem liczby wiernych (w stosunku do lat przedwojennych) nie widziano też potrzeby dalszego funkcjonowania prawosławnych parafii ${ }^{7}$.

${ }^{4}$ Ibidem, s. 352-353.

5 Болбардировка съ аэроплана Лолжинскаго собора, „Варшавскій Епархіалный Листокъ”, 16 IV 1915, № 8, s. 102-103; Вторичная бомбардировка Ломжинскаго собора нглецкиль аэропланоль, „Варшавскій Епархіалный Листокъ”, 16 V 1915, № 10, s. 130-131.

${ }^{6}$ Łomżę Niemcy opuścili 12 XI 1918 r. Inaczej było w przypadku Suwałk i Augustowa, gdzie stało się to dopiero w ostatnim tygodniu sierpnia $1919 \mathrm{r}$. W tym czasie, w związku z zajęciem powiatu sejneńskiego przez Litwinów, Polska Organizacja Wojskowa zorganizowała powstanie, które na początku września doprowadziło do ich wyparcia poza linię Focha. Po raz kolejny Litwini zajęli Suwalszczyznę po Augustów podczas ofensywy bolszewików na Warszawę w sierpniu 1920 r. W związku z jej porażka, po zaciętych walkach, zostali ponownie wyparci za linię Focha. 7 października w Suwałkach podpisano zawieszenie broni, które na opisywanym terenie zakończyło działania militarne. Zob. m.in.: A.Cz. Dobroński, Łomża w latach 1866-1918, Łomża-Białystok 1993, s. 219-220; P. Łossowski, Konflikt polsko-litewski 1918-1920, Warszawa 1996, s. 46-52, 65-68, 138-155.

7 W tym kontekście apele władz Kościoła prawosławnego, również o przyznanie praw do użytkowanych przed wojną majątków, innych niż cerkwie, były całkowicie marginalizowane. 
Ogólna zgoda odnośnie do likwidacji świątyń kończyła się jednak w chwili, gdy należało ustalić, jaką przybierze postać: czy będzie to rozbiórka, czy adaptacja? Co stanie się z materiałem rozbiórkowym? Co powstanie w miejscu cerkwi? Komu powinno przysługiwać prawo użytkowania placu pocerkiewnego lub adaptacji do innych celów opustoszałych murów?

W niniejszym opracowaniu ów złożony problem przedstawię w oparciu o losy świątyń w Suwałkach, Łomży i Augustowie. Na ich podstawie postaram się ukazać pewne prawidłowości czy schematy postępowania z prawosławnym dziedzictwem, charakterystyczne nie tylko na poziomie lokalnym (trzy wybrane miasta) czy regionalnym (teren byłych guberni suwalskiej i łomżyńskiej ${ }^{8}$ ), ale też całego Królestwa Polskiego9 .

Trzy wybrane ośrodki do końca 1866 r. położone były na terenie guberni augustowskiej z siedzibą w Suwałkach. Po tej dacie gubernię podzielono na dwie mniejsze jednostki administracyjne, utrzymując stolicę nad Czarna Hańcza, a na południu lokując ją w Łomży. Największy wpływ na powstanie cerkwi w tych miastach wywarł wyróżniający je z krajobrazu regionu rolniczego charakter urzędowy. W obu ośrodkach przebywała największa, w skali regionu, liczba Rosjan zatrudnionych w administracji, a także znajdowały się tu specjalnie utworzone garnizony wojskowe. Warto $\mathrm{w}$ tym miejscu również zauważyć, że budowę pierwszej cerkwi w Suwałkach - już w latach 18381893 - motywowano obecnością w okolicy sporej grupy staroobrzędowców ${ }^{10}$, w których z jednej strony władze rosyjskie widziały zagrożenie (zły wpływ na żołnierzy), z drugiej zaś potencjalna grupę wiernych ${ }^{11}$. Augustów natomiast był jednym z największych miast na prawach powiatu. Jego okolice, podobnie jak

${ }^{8}$ Obszar guberni suwalskiej i łomżyńskiej został podzielony na dziewięć powiatów w obrębie województwa białostockiego: suwalski, sejneński (włączony do suwalskiego w 1925 r.), augustowski, szczuczyński, kolneński, łomżyński, wysoko-mazowiecki, ostrołęcki, ostrowski. W granicach województwa mazowieckiego znalazł się powiat makowski, w granicach województwa lubelskiego - powiat węgrowski (w guberni łomżyńskiej od 1912 r.). Powiaty mariampolski i kalwaryjski przyłączono do Litwy (nie będę odwoływał się do wybudowanych tam cerkwi).

${ }^{9}$ Chodzi o Królestwo Polskie bez guberni chełmskiej, wydzielonej w latach 1912-1915 i włączonej do Imperium Rosyjskiego. Na jej terenie mieszkał znaczny odsetek unitów, którzy po likwidacji unii w Królestwie Polskim w 1875 r. zostali przymusowo przypisani do prawosławia. Zob. m.in.: A. Wrzyszcz, Gubernia chetmska. Zarys ustrojowy, Lublin 1997.

10 Staroobrzędowcy - odłam Rosyjskiego Kościoła Prawosławnego nieuznający reformy liturgicznej patriarchy Nikona z połowy XVII w. - pojawili się na ziemi suwalsko-sejneńskiej w pierwszej połowie XVIII w. Później osiedlili się także w regionie augustowskim i na Mazurach. Zob. m.in.: E. Iwaniec, Osadnictwo staroobrzędowców w powiecie augustowskim, w: Studia i materiaty do dziejów Pojezierza Augustowskiego, red. J. Antoniewicz, Białystok 1967, s. 403.

11 A. Matusiewicz, Światynie w Suwatkach w XIX wieku, „Rocznik Augustowsko-Suwalski” 2012, t. XII, s. 49-52. Na temat pierwszej suwalskiej cerkwi zob. też: P. Paszkiewicz, W służbie Imperium Rosyjskiego 1721-1917. Funkcje i treści ideowe rosyjskiej architektury sakralnej na zachodnich rubieżach cesarstwa i poza jego granicami, Warszawa 1999, s. 82. 
wschodnią część guberni łomżyńskiej, zamieszkiwali unici. Byli to potomkowie osiadłej tu niegdyś prawosławnej ludności ruskiej, która następnie przyłączyła się do Kościoła katolickiego i spolonizowała się. W połowie XIX w., w obrębie diecezji chełmskiej, unicki dekanat augustowski skupiał 9 parafii, na terenie których znajdowało się 10 świątyń (m.in. w Augustowie) ${ }^{12}$. W 1875 r. władze carskie, pod przymusem, przypisały zarówno wiernych, jak i ich miejsca kultu do prawosławia.

Zarysowane różnice $\mathrm{w}$ obrębie pochodzenia wiernych oraz służących im cerkwi nie wpłynęły na ogólny obraz prawosławia na terenie wymienionych miast, jako wyznania rosyjskich władz rządowych, podległej im administracji oraz wojska. Ubytek tych grup w czasie wojny trafnie oddawała statystyka przeprowadzona przez władze wojewódzkie w Białymstoku w połowie lat dwudziestych XX w. Według niej w obrębie całego województwa mieszkało przeszło 243 tys. prawosławnych, z tym jednak, że na 9 zachodnich powiatów, wchodzących wcześniej w skład guberni łomżyńskiej i suwalskiej, przypadało ich jedynie $2248^{13}$. Niezależnie od dokładności tych danych należy stwierdzić, że była to liczba dużo niższa od przedwojennej, gdyż w 1913 r. samą tylko gubernię łomżyńską zamieszkiwało przeszło trzykrotnie więcej (bez wojska) ${ }^{14}$ prawosławnych.

Problematyka cerkwi prawosławnych na opisywanym terenie, w interesującym nas przedziale czasowym, nie została objęta dotychczas osobnym opracowaniem. Wyjątkiem $\mathrm{w}$ tym zakresie jest publikacja, przygotowana w Łomży z okazji 10. rocznicy zwycięstwa w wojnie polsko-bolszewickiej, w której szczegółowo skupiono się na adaptacji jednej z tamtejszych świątyń wojskowych na Dom Żołnierza ${ }^{15}$. Wśród opracowań współczesnych na wyróżnienie zasługują te autorstwa Sergiusza Borowika, Andrzeja Matusiewicza,

${ }^{12} \mathrm{O}$ augustowskim dekanacie unickim można mówić w tym czasie jedynie z nazwy. Według liczby spowiadających się w 1847 r. zamieszkiwało go jedynie siedmiu unitów. Największe grupy wiernych występowały we wschodniej części powiatu augustowskiego. W parafii w Balli Kościelnej było to 1812 wiernych, w parafii w Lipsku - 1719, w parafii w Perstuniu - 2045 (dane dla 1870 r.). W. Jemielity, Dekanat unicki augustowski w XIX i poczatkach XX wieku, w: Materiały do dziejów społeczno-religijnych w Polsce, red. Z. Sułowski, E. Wiśniowski, Lublin 1974, s. 159. Rozmieszczenie grup wyznaniowych na terenie guberni augustowskiej obrazuje mapa: Archiwum Główne Akt Dawnych, Zbiór kartograficzny, sygn. 8-5, Карта народонаселенія Августовской губерніи по исповъданіямъ и племенамъ. Составлена Генеральнаго Штаба Подполковникомъ А. Риттихъ, [1865].

${ }^{13}$ Archiwum Państwowe w Białymstoku (dalej: APB), Urząd Wojewódzki Białostocki (dalej: UWB), sygn. 33, Szczegółowe sprawozdanie o parafiach prawosławnych na terenie woj. białostockiego jako komentarz do kwestionariusza - dane ogólne, [1926], k. 2.

${ }_{14}$ W. Jemielity, Łomżyński Dziekanat Prawostawny, „Studia Teologiczne” 1996, t. XIV, s. 190.

${ }^{15}$ Na otwarcie Domu Żotnierza i dziesięciolecie obrony Łomży 1920-1930, Łomża 1930 (reprint z 2000 r. przygotowany do druku przez H. Wiśniewskiego). Za udostępnienie książki autor serdecznie dziękuje panu Danielowi Frąckiewiczowi z Miejskiej Biblioteki Publicznej w Łomży. 
Krzysztofa Skłodowskiego (cerkwie w Suwałkach) ${ }^{16}$, o. Grzegorza Sosny i m. Antoniny Troc-Sosny (cerkiew w Augustowie) ${ }^{17}$ oraz Witolda Jemielitego (cerkwie w Łomży $)^{18}$.

Żaden z wymienionych badaczy nie powołał się w swych rozważaniach na materiały archiwalne zgromadzone w Archiwum Akt Nowych (AAN). W kontekście niezachowania się dokumentacji wytworzonej przez władze samorządowe ${ }^{19}$, przy tylko fragmentarycznie zachowanych aktach władz wojewódzkich w Białymstoku ${ }^{20}$ oraz niezadowalających wynikach kwerendy $\mathrm{w}$ prasie regionalnej ukazującej się $\mathrm{w}$ międzywojniu ${ }^{21}$, mają one dla przyjętego tematu wartość kluczowa. Informacje odnośnie do liczebności żołnierzy wyznania prawosławnego, jak i służących im miejsc kultu, udało się ustalić podczas kwerendy przeprowadzonej w Centralnym Archiwum Wojskowym (CAW). Pretensje władz Kościoła katolickiego zobrazował zaś w pewnym stopniu materiał zgromadzony w Archiwum Diecezjalnym w Łomży (ADŁ) oraz Archiwum Diecezjalnym w Ełku ${ }^{22}$. Nowych ustaleń dostarczyć mogą poszukiwania w Archiwum Warszawskiej Metropolii Prawosławnej, których nie udało się przeprowadzić w czasie przeznaczonym na powstanie niniejszego artykułu.

\section{Świątynie prawosławne w przededniu I wojny światowej}

Budownictwo sakralne, które u progu rozpoczęcia Wielkiej Wojny znajdowało się w posiadaniu prawosławnych, można podzielić na obiekty służące wojskowym oraz świeckim, choć zdarzało się, że dla jednych i drugich organizowano wspólne nabożeństwa (np. podczas świąt państwowych, wizyt ważnych osobistości itp.). Działo się tak zapewne częściej w okresie poprzedzającym

16 S. Borowik, Parafia w Suwatkach, „Przegląd Prawosławny” 2010, nr 9, s. 24-27; A. Matusiewicz, Światynie..., s. 49-57; K. Skłodowski, Infrastruktura oraz „terenowe wyposażenie” garnizonu Suwatki (1922-1939), „Rocznik Augustowsko-Suwalski” 2007, t. VII, s. 35-50; idem, Stużba duszpasterska w garnizonie Suwatki 1921-1939, „Rocznik Augustowsko-Suwalski” 2012, t. XII, s. 59-76.

${ }_{17}$ G. Sosna, A. Troc-Sosna, Zapomniane dziedzictwo. Nie istniejace już cerkwie $w$ dorzeczu Biebrzy i Narwi, Białystok 2002, s. 19-33.

${ }_{18}$ W. Jemielity, Łomżyński Dziekanat Prawosławny..., s. 181-207; idem, Dzieje Łomży tysiacletnie. Zarys historii miasta, Łomża 2005.

${ }_{19}$ Miejskie i powiatowe w Archiwum Państwowym w Suwałkach oraz Archiwum Państwowym w Białymstoku Oddział w Łomży.

${ }^{20}$ W Archiwum Państwowym w Białymstoku.

${ }^{21}$ Poszukiwania przeprowadzono w wybranych numerach następujących czasopism: „Dziennik Białostocki” (1926), „Dziennik Suwalski” (1926), „Gazeta Łomżyńska” (lata 1919-1923), „Nasz Głos” (lata 1932-1939), „Wiadomości Urzędowe Inspektoratu Szkolnego Powiatu Augustowskiego” (lata 1926-1933), „Ziemia Suwalska” (1919).

${ }^{22} \mathrm{~W}$ wypadku archiwaliów zgromadzonych w Ełku, dotyczących przekształcenia soboru Zaśnięcia Najświętszej Maryi Panny na kościół Najświętszego Serca Pana Jezusa, powołałem się na badania K. Skłodowskiego. 
Tabela 1. Wykaz świątyń na terenie Suwałk, Łomży i Augustowa z podziałem na obiekty obsługiwane przez prawosławne duchowieństwo wojskowe i diecezjalne

\begin{tabular}{|c|c|c|c|}
\hline \multicolumn{4}{|c|}{ Cerkwie obsługiwane przez duchowieństwo wojskowe } \\
\hline Miejscowość & Wezwanie cerkwi & $\begin{array}{c}\text { Czas } \\
\text { powstania }\end{array}$ & Lokalizacja \\
\hline \multirow[t]{3}{*}{ Suwałki } & $\begin{array}{l}\text { Cerkiew św. Jerzego Zwycięzcy } 2 \\
\text { Lejb-Huzarskiego Pawłogrodzkiego } \\
\text { Pułku Imperatora Aleksandra III }\end{array}$ & 1900 & $\begin{array}{l}\text { Koszary przy Szosie } \\
\text { Sejneńskiej }\end{array}$ \\
\hline & $\begin{array}{l}\text { Cerkiew domowa św. Mikołaja } \\
\text { Cudotwórcy } 2 \text { Lejb-Dragońskiego } \\
\text { Pskowskiego Pułku Imperatorowej } \\
\text { Marii Fiodorowny }\end{array}$ & 1900 & $\begin{array}{l}\text { Koszary za rogatką } \\
\text { augustowską }\end{array}$ \\
\hline & $\begin{array}{l}\text { Cerkiew św. Aleksandra Newskiego } \\
5 \text { Strzeleckiej Brygady }\end{array}$ & $1904-1907$ & $\begin{array}{l}\text { Koszary za rogatka } \\
\text { augustowską }\end{array}$ \\
\hline \multirow[t]{3}{*}{ Łomża* } & $\begin{array}{l}\text { Cerkiew św. Apostołów Piotra } \\
\text { i Pawła } 14 \text { Ołonieckiego Pułku } \\
\text { Piechoty }\end{array}$ & XIX/XX w. & $\begin{array}{l}\text { Róg ul. Polowej i Szosy } \\
\text { Śniadowskiej }\end{array}$ \\
\hline & $\begin{array}{l}\text { Cerkiew św. Mikołaja Cudotwórcy } \\
13 \text { Biełozierskiego Pułku Piechoty }\end{array}$ & 1895 & $\begin{array}{l}\text { Koszary przy Szosie } \\
\text { Śniadowskiej }\end{array}$ \\
\hline & $\begin{array}{l}\text { Kaplica na wojskowym cmentarzu } \\
\text { prawosławnym (wezwania nie } \\
\text { ustalono) }\end{array}$ & $\mathrm{XIX} / \mathrm{XX} \mathrm{w}$. & $\begin{array}{l}\text { Południowa część miasta, } \\
\text { w pobliżu koszar, obecnie } \\
\text { ul. Kard. S. Wyszyńskiego }\end{array}$ \\
\hline Augustów & $\begin{array}{l}\text { Cerkiew św. Mikołaja Cudotwórcy } \\
104 \text { Ustiużskiego Pułk Piechoty } \\
\text { im. Ks. Bagrationa }\end{array}$ & $\begin{array}{l}\text { między } 1896 \\
\text { a } 1909\end{array}$ & $\begin{array}{l}\text { Koszary przy drodze } \\
\text { w kierunku Suwałk }\end{array}$ \\
\hline \multicolumn{4}{|c|}{ Cerkwie obsługiwane przez duchowieństwo diecezjalne } \\
\hline \multirow[t]{3}{*}{ Suwałki } & $\begin{array}{l}\text { Sobór Zaśnięcia Najświętszej Maryi } \\
\text { Panny }\end{array}$ & $\begin{array}{l}\text { 1838-1840, } \\
\text { przebudowany } \\
\text { w latach 1879- } \\
1881,1893-1894\end{array}$ & $\begin{array}{l}\text { Południowa część parku } \\
\text { miejskiego, naprzeciw } \\
\text { kościoła (katolickiego) } \\
\text { św. Aleksandra }\end{array}$ \\
\hline & $\begin{array}{l}\text { Cerkiew szkolna św. Mikołaja } \\
\text { Cudotwórcy }\end{array}$ & 1897 & $\begin{array}{l}\text { Gimnazjum rządowe, } \\
\text { w miejscu wcześniejszej } \\
\text { kaplicy katolickiej }\end{array}$ \\
\hline & Cerkiew Wszystkich Świętych & $1891-1893$ & Cmentarz prawosławny \\
\hline \multirow[t]{3}{*}{ Łomża } & Sobór św. Trójcy & $1873-1877$ & $\begin{array}{l}\text { Pl. Soborny (obecnie Jana } \\
\text { Pawła II) }\end{array}$ \\
\hline & Cerkiew więzienna św. Mikołaja** & 1896 & $\begin{array}{l}\text { Więzienie carskie przy } \\
\text { obecnej Alei Legionów }\end{array}$ \\
\hline & $\begin{array}{l}\text { Kaplica cmentarna Grobu } \\
\text { Pańskiego }\end{array}$ & 1906 & $\begin{array}{l}\text { Kompleks cmentarzy wie- } \\
\text { lowyznaniowych - czesść } \\
\text { prawosławna (zachodnia), } \\
\text { obecnie ul. M. Kopernika }\end{array}$ \\
\hline \multirow[t]{2}{*}{ Augustów } & $\begin{array}{l}\text { Cerkiew św. Apostołów Piotra } \\
\text { i Pawła }\end{array}$ & $1881-1884$ & Płd.-zach. część rynku \\
\hline & $\begin{array}{l}\text { Cerkiew Kazańskiej Ikony Matki } \\
\text { Bożej (pounicka) }\end{array}$ & XVIII w. & $\begin{array}{l}\text { Róg ul. Koziej i Ruskiej, } \\
\text { nad rzeką Nettą }\end{array}$ \\
\hline
\end{tabular}


Źródła: Archiwum Akt Nowych, Ministerstwo Wyznań Religijnych i Oświecenia Publicznego, sygn. 980, Statystyka ludności prawosławnej, duchownych, parafii, cerkwi oraz realności, należących niegdyśs do parafii prawosławnych - Łomża, Suwałki, [1919], s. 114, 232-233; ibidem, sygn. 1061, UWB do MWRiOP w sprawie parafii prawosławnej w Suwałkach, 24 II 1923, s. 504; Archiwum Państwowe w Białymstoku, Urząd Wojewódzki Białostocki, sygn. 148, Spis zabytków województwa białostockiego, [lata 30. XX w.], k. 2; Archiwum Państwowe w Białymstoku Oddział w Łomży, Mapy i plany XVII-XX w. Zbiór kopii i fotokopii, sygn. 7, Stadt-Plan von Łomza. Aufgestellt Lomza im Dezember 1915; P. Cynalewska-Kuczma, Architektura cerkiewna Królestwa Polskiego narzędziem integracji z Imperium Rosyjskim, Poznań 2004, s. 130, 142, 149-150; A. Matusiewicz, Światynie w Suwałkach w XIX wieku, „Rocznik Augustowsko-Suwalski” 2012, t. XII, s. 50-57; K. Skłodowski, Infrastruktura oraz „terenowe wyposażenie” garnizonu Suwatki (1922-1939), „Rocznik Augustowsko-Suwalski” 2007, t. VII, s. 39; K. Sokoł, A. Sosna, Cerkwie w centralnej Polsce 1815-1915, Białystok 2011, s. 165; J. Szlaszyński, Od pierwszej do drugiej wojny światowej, w: Augustów. Monografia historyczna, red. J. Szlaszyński, A. Makowski, Augustów 2007, s. 158, 177, 188; W. Jemielity, Eomżyński Dziekanat Prawostawny, „Studia Teologiczne” 1996, t. XIV, s. 199-200; Wykaz zabytków nieruchomych wpisanych do rejestru zabytków (woj. podlaskie) - stan na 30 IX 2015 r., http://www.nid.pl/pl/Informacje_ogolne/ Zabytki_w_Polsce/rejestr-zabytkow/zestawienia-zabytkow-nieruchomych/stan\%20na\%2030.09.2015/ PDL-rej.pdf (dostęp: 15 XI 2015).

* W zebranym materiale źródłowym nie odnalazłem żadnych wzmianek na temat przeznaczenia tej cerkwi po 1918 r., być może zlikwidowano ja już w czasie wojny.

budowę cerkwi wojskowych (wszystkie powstały na przełomie XIX i XX w.). Ponadto odnotowano wspólne inicjatywy wznoszenia świątyń, czego przykładem może być sobór i cerkiew Wszystkich Świętych w Suwałkach. O budowę obu obiektów zabiegali wojskowi (w pierwszym wypadku naczelnik wojenny województwa augustowskiego płk Klemens Rutkowski, w drugim - dowódca miejscowego garnizonu gen. mjr Mikołaj Krzywicki) ${ }^{23}$.

Zwraca uwagę prestiżowa lokalizacja, zarówno suwalskiego soboru i cerkwi św. Apostołów Piotra i Pawła w Augustowie wzniesionych na terenie rynku, jak również łomżyńskiego soboru św. Trójcy powstałego w jego bezpośredniej okolicy. W ten sposób, jak już zaznaczyłem, podkreślano wyższość i wyjątkowość wyznania władz rządowych, co w konsekwencji wywoływało wrogie nastroje wśród ludności polskiej. Dla prawosławnej młodzieży powstała w Suwałkach cerkiew szkolna - w miejscu zlikwidowanej kaplicy katolickiej $\mathrm{w}$ gimnazjum rządowym. Osadzeni w łomżyńskim więzieniu mogli natomiast korzystać ze zorganizowanej w jego murach cerkwi św. Mikołaja ${ }^{24}$. Na terenie wybranych trzech miast założono prawosławne nekropolie w obrębie cmentarzy wielowyznaniowych. O statusie Suwałk i Łomży oraz majętności zamieszkałej na ich terenie ludności prawosławnej świadczyły wzniesione tu cmentarna cerkiew i kaplica. Na przedmieściach Łomży i przy cerkwi św. Aleksandra Newskiego w Suwałkach powstały też nekropolie ze specjalnym przeznaczeniem dla wojska. Podkreślenia wymaga to, że przy większości

${ }^{23}$ A. Matusiewicz, Światynie..., s. 50, 55.

${ }^{24}$ K. Sokoł, A. Sosna, Cerkwie w centralnej Polsce 1815-1915, Białystok 2011, s. 165; A.Cz. Dobroński, M. Zwolski, Sto lat w cieniu 40 kominów, „Kurier Poranny Magazyn”, 10 VI 2012, nr 130 (dodatek „Album Białostocki”), s. 17. 
świątyń znajdowały się również murowane stróżówki, budynki mieszkalne i gospodarcze. Duchowieństwo diecezjalne uposażono też dodatkowo w ogrody warzywne, sady, pola orne i łąki. Wykaz wszystkich świątyń powstałych przed 1915 r. obrazuje tabela 1.

\section{Bilans okupacji niemieckiej}

Użytkowanie cerkwi jako lazaretów wojskowych dla rannych żołnierzy i chorych na tyfus (sobór i cerkiew gimnazjalna w Suwałkach) miało najpewniej charakter tymczasowy i związane było z bliskościa prowadzonych walk na froncie. Po ich ustabilizowaniu świątynie uzyskały bardziej trwałe funkcje. Wtedy też niemieckie dowództwo podjęło się zorganizowania obiektów, w których żołnierze mogliby zaspokoić swoje potrzeby religijne.

Ze statystyk prowadzonych bezpośrednio po wojnie i w latach dwudziestych przez Ministerstwo Wyznań Religijnych i Oświecenia Publicznego (MWRiOP) i władze wojewódzkie w Białymstoku wiadomo, że sobory w Suwałkach i w Łomży zostały zamienione przez Niemców na kościoły garnizonowe (odnośnie do Łomży podano 1915 r. $)^{25}$. Można przypuszczać, że podobnie stało się z cerkwią na augustowskim rynku, gdyż bezpośrednio przy niej wyznaczono miejsce na pochówki poległych żołnierzy ${ }^{26}$.

Światynie wykorzystywano też na cele dalekie od kultowych, a wpisujace się w potrzeby aprowizacyjne i logistyczne prowadzonej wojny. Świadczą o tym przykłady z innych regionów okupowanego Królestwa Polskiego, gdzie cerkwie stały się magazynami (św. Mikołaja Cudotwórcy w Kielcach i św. Apostołów Piotra i Pawła w Warszawie) czy obozami jenieckimi (sobór Wniebowstapienia Pańskiego w Kielcach). Nie inaczej było na opisywanym terenie. W świątyni Kazańskiej Ikony Matki Bożej miano pomieścić kuźnię²7, suwalska cerkiew św. Aleksandra Newskiego stała się zaś składem żywnościowym ${ }^{28}$. Funkcje magazynowe uzyskała też najpewniej cerkiew św. Jerzego za rogatką sejneńska, o czym świadczył duży stopień jej dewastacji w okresie powojennym ${ }^{29}$.

Już w czasie wojny dochodziło do przekazywania świątyń miejscowej ludności wyznania katolickiego. Szczególnie dotyczyło to tych, które władze rosyjskie odebrały wcześniej unitom i przemianowały na prawosławne. W październiku

${ }^{25}$ Archiwum Akt Nowych (dalej: AAN), Ministerstwo Wyznań Religijnych i Oświecenia Publicznego (dalej: MWRiOP), sygn. 1206, Wykaz zamkniętych i nieczynnych jako parafialne względnie filialne etatowe cerkwie prawosławne w pow. suwalskim i łomżyńskim, [1925-1926], s. 27-28.

${ }^{26}$ Ibidem, sygn. 1208, Wniosek MRP w sprawie rozbiórki cerkwi prawosławnej stojącej bez użytku rynku w Augustowie, [1925], s. 302.

${ }^{27}$ K. Sokoł, A. Sosna, op. cit., s. 32.

${ }^{28}$ AAN, MWRiOP, sygn. 1206, Wykaz zamkniętych i nieczynnych jako parafialne... - pow. suwalski, [1925-1926], s. 27.

${ }^{29}$ S. Borowik, op. cit., s. 25. 
1915 r. parafię katolicką utworzono przy cerkwi Zaśnięcia Najświętszej Maryi Panny w Hodyszewie, a rok później stało się tak z cerkwiami w powiecie augustowskim: w Hołynce, Perstuniu i Rygałówce ${ }^{30}$. Według MWRiOP w tym samym czasie katolicy przejęli cerkiew na terenie żeńskiego klasztoru prawosławnego w Teolinie (do 1878 r. był to kościół katolicki) ${ }^{31}$. W Suwałkach zaś, latem 1918 r., Niemcy przekazali na potrzeby parafii św. Aleksandra wymienianą wcześniej świątynię garnizonową na przedmieściach. Tak tłumaczył to proboszcz ks. Stanisław Szczęsnowicz: „Do roku 1918 suwalska szesnastutysięczna parafja Rz.-Kat. miała w Suwałkach tylko jeden kościół [św. Aleksandra - P.Z.], do którego na sumę w dni niedzielne i świąteczne mogła pomieścić się tylko część wiernych, a reszta modliła się nieraz na deszczu i słocie przed kościołem, pod gołym niebem. Widząc to okupanci Niemcy oddali do użytku parafji cerkiew stojąca pustkami za miastem i dom dla księdza, usunąwszy z niego swoich oficerów, którzy tam podówczas mieszkali [...]”32.

Również za zgodą władz niemieckich zajęte zostały byłe już sobory w Suwałkach i Łomży. Pierwszy duszpasterstwo przekazało na świątynię dla uczącej się młodzieży ${ }^{33}$. Drugi stał się, na początku czerwca lub lipca 1917 r., kościołem garnizonowym dla stacjonującego w Łomży 4 Pułku Legionów ${ }^{34}$. Taką funkcję pełnił jednak krótko, bo już w połowie lipca - w związku z „kryzysem przysięgowym” legionistów wycofano i internowano w obozach w Beniaminowie i Szczypiornie ${ }^{35}$.

W perspektywie roku 1919 najgorzej przedstawiał się stan pounickiej cerkwi w Augustowie, co potwierdzałoby przeznaczenie jej na kuźnięę. Źle wojnę przetrwać miały też cerkwie łomżyńskie ${ }^{37}$. Odnośnie do obiektów w Suwałkach zapisano, że „wszystkie [...] uległy w czasie wojny mniejszym lub większym uszkodzeniom i wymagają remontu" ${ }^{38}$. Wyjątkiem w tym kontekście miała być świątynia na rynku w Augustowie, która jako jedyna zachowała się w dobrym stanie technicznym ${ }^{39}$.

${ }^{30}$ AAN, MWRiOP, sygn. 1206, Wykaz zamkniętych i nieczynnych jako parafialne... - pow. augustowski, [1925-1926], s. 23-24.

${ }^{31}$ Ibidem.

${ }^{32}$ Ibidem, sygn. 1220, Proboszcz parafii św. Aleksandra w Suwałkach ks. S. Szczęsnowicz do biskupa w Łomży w sprawie byłej cerkwi pułków piechoty rosyjskiej, 16 I 1922, s. 288-292.

${ }^{33}$ A. Matusiewicz, Dzieje cerkwi Zaśnięcia Matki Boskiej, w: Wyjatkowa parafia, krótkie opisanie kościoła i parafii pod wezwaniem Najświętszego Serca Pana Jezusa w Suwatkach, red. J. Bacewicz, Suwałki 2007, s. 49.

${ }_{34}$ A.Cz. Dobroński, op. cit., s. 213; W. Jemielity, Dzieje Łomży..., s. 211.

35 A. Lewicki, Zarys historji wojennej 4-go Putku Piechoty Legjonów, Warszawa 1929, s. 17-19.

36 AAN, MWRiOP, sygn. 1206, Wykaz świątyń prawosławnych w powiatach augustowskim, grodzieńskim, kolneńskim, ostrołęckim, wys.-mazowieckim i wołkowyskim przesłany przez wojewodę białostockiego do MWRiOP, 5 XI 1928, s. 52.

${ }^{37}$ Ibidem, sygn. 980, Statystyka ludności prawosławnej, duchownych, parafii, cerkwi oraz realności, należących niegdyś do parafii prawosławnych - Łomża, [1919], s. 114.

${ }^{38}$ Ibidem, Statystyka ludności... - Suwałki, [1919], s. 232-233.

${ }^{39}$ Ibidem, Statystyka ludności... - Augustów, [1919], s. 234-235. 


\section{Cerkwie zaadaptowane na katolickie kościoły garnizonowe}

Przejście armii na organizację pokojową po zakończeniu wojny polsko-bolszewickiej wiązało się z podziałem kraju na 10 okręgów korpusów i tworzeniem na ich terenie struktur duszpasterstwa wojskowego. Jego zadaniem, pod kontrolą wojskową i administracyjną Ministerstwa Spraw Wojskowych (MSW), było sprawowanie opieki religijnej nad żołnierzami, którzy, podobnie jak społeczeństwo II Rzeczypospolitej, stanowili społeczność wielowyznaniowa. Pod względem liczby, jak i złożoności struktury organizacyjnej dominowało duszpasterstwo wyznania katolickiego ${ }^{40}$.

W związku z przemieszczeniem jednostek wojskowych do Suwałk i Augustowa (znalazły się na terenie Dowództwa Okręgu Korpusu [DOK, III w Grodnie]) oraz Łomży (obszar DOK I w Warszawie) pojawiła się potrzeba zapewnienia obiektów, które mogłyby pełnić rolę świątyń garnizonowych. Praktyka, zarówno na terenie DOK III (Nowo Wilejka, Wołkowysk, Białystok), jak i DOK I (Ostrołęka, Zegrze), było przeznaczenie na ten cel cerkwi opuszczonych przez garnizony rosyjskie ${ }^{41}$. Podobnie sytuacja przedstawiała się w opisywanych miejscowościach. Duży stopień dewastacji koszar (zwłaszcza w Suwałkach i Augustowie), a także zniszczenia w obrębie samych świątyń spowodowały, że znaczących nakładów finansowych i czasu wymagało przywrócenie ich do stanu używalności.

Zapewne najszybciej przystapiono do powołania parafii wojskowej w Łomży. Stacjonujący tam przez cały okres międzywojenny 33 Pułk Piechoty zaczęto formować niezwłocznie po rozbrojeniu i wycofaniu się Niemców. Z wykazu sporządzonego rok później (bez podania dokładniejszej daty) wynikało, że żadna ze znajdujących się w mieście świątyń nie była użytkowana. Zmiany przyniosły jednak najbliższe lata. Jeszcze przed marcem 1923 r. do celów sakralnych przeznaczono aż dwie cerkwie. Były to sobór św. Trójcy oraz cerkiew św. Mikołaja Cudotwórcy w koszarach przy Szosie Śniadowskiej ${ }^{42}$. Według Wojciecha Guzewicza nowo utworzonej parafii nadano wezwanie

${ }^{40}$ Miało to swoje odzwierciedlenie w liczbie żołnierzy tego wyznania. Według danych z $1926 \mathrm{r}$. katolicy stanowili w wojsku $72,61 \%$, prawosławni - 11,88\%, grekokatolicy $-7,75 \%$, Żydzi - 5,26\%, protestanci - 2,17\%, muzułmanie - 0,01\%. J. Odziemkowski, B. Spychała, Duszpasterstwo wojskowe w Drugiej Rzeczypospolitej, Warszawa 1987, s. 192. Nieco inne dane dla roku 1927 przedstawił Jan Kęsik, nadal jednak dominowali katolicy (76,11\%), a prawosławni byli największą mniejszością religijną (10,47\%). J. Kęsik, Naród pod bronia. Społeczeństwo w programie polskiej polityki wojskowej 1918-1939, Wrocław 1998, s. 171.

${ }^{41}$ Dla DOK III zob. U. Kraśnicka, Organizacja rzymskokatolickiego duszpasterstwa wojskowego na terenie DOK III Grodno w latach 1921-1939, „Zeszyt Naukowy Muzeum Wojska w Białymstoku" 1998, z. 11, s. 62-63.

${ }^{42}$ AAN, MWRiOP, sygn. 1215, Wojewoda białostocki do MWRiOP w sprawie b. cerkwi garnizonowej w Łomży przy ul. Polowej, 28 III 1923, s. 84-85; ibidem, sygn. 1206, Wykaz zamkniętych i nieczynnych jako parafialne... - pow. łomżyński, [1925-1926], s. 26. 
Wniebowzięcia Najświętszej Maryi Panny ${ }^{43}$. Trudno wyjaśnić konieczność adaptacji do celów wojskowych aż dwóch obiektów, gdyż w Łomży, poza wskazanym pułkiem, nie funkcjonowały w latach dwudziestych inne jednostki. Możliwe, iż stało się tak ze względu na znajdujący się tu sztab 18 Dywizji Piechoty, a także znaczne oddalenie cerkwi św. Mikołaja od centrum miasta. Można przypuszczać, że takie decyzje były spowodowane również wykorzystywaniem soboru jako kościoła garnizonowego przez legionistów w czasie wojny. Skape materiały źródłowe nie mówią nic o okolicznościach przejęcia i prosperowania tych świątyń. Wiadomo jedynie, że o bezpłatne odstapienie całej „nieruchomości pocerkiewnej” ubiegały się władze miejskie ${ }^{44}$, jednak ostatecznie, na mocy decyzji MSW z 27 XI 1927 r., przeszła ona w posiadanie parafii katedralnej ${ }^{45}$. Miało się tak stać z uwagi na zły stan techniczny świątyni i brak subsydiów na podjęcie prac remontowych (nie prowadzono ich od czasu objęcia przez władze wojskowe) ${ }^{46}$.

W pierwszych latach po zakończeniu wojny polsko-bolszewickiej dla oddziałów wojskowych przydzielonych do Suwałk nabożeństwa odprawiano w kościele parafialnym św. Aleksandra oraz w dwóch kaplicach zorganizowanych na terenie koszar ${ }^{47}$. Na jedna z nich (Matki Boskiej Częstochowskiej) zaadaptowano domową cerkiew garnizonową św. Mikołaja w byłych koszarach strzeleckich, które w nowych warunkach stały się siedzibą 41 Suwalskiego Pułku Piechoty ${ }^{48}$. Z uwagi na liczbę żołnierzy przebywających na stałe w mieście, wahająca się od ok. 5 do 6 tys., były to warunki daleko niewystarczające. W zwiazku z tym MSW wystapiło do MWRiOP o przydział dla żołnierzy jednej z suwalskich świątyń, co przez wiele miesięcy stanowiło powód sporu między dowództwem garnizonu a miejscową parafią. Wojskowi zażądali bowiem udostępnienia byłej cerkwi, a obecnie kościoła św. Apostołów Piotra i Pawła. Ten zaś przekazały suwalskiemu duchowieństwu władze niemieckie, a ich decyzję 19 XI 1919 r. zatwierdziło MWRiOP w porozumieniu z Ministerstwem

${ }_{43}$ W. Guzewicz, Duszpasterstwo wojskowe na terenie diecezji tomżyńskiej w latach 1918-1939, „Roczniki Teologiczne” 2001, t. XLVIII, z. 4, s. 166. Autor stwierdził, że parafia nosiła takie wezwanie przez cały okres międzywojenny. Nie uwzględnił jednak faktu przekazania świątyni duchowieństwu diecezjalnemu, podobnie jak istnienia drugiego kościoła garnizonowego na terenie koszar.

${ }^{44}$ Kronika. Z Rady Miejskiej, „Gazeta Łomżyńska”, 3 VII 1923, nr 11, s. 2.

${ }^{45}$ Podczas przekazania obiektu zastrzeżono, że garnizon wojskowy nadal będzie uczestniczył w mszach św. w kościele, jednak mają być one odprawiane przez duchowieństwo diecezjalne. AAN, MWRiOP, sygn. 1215, MRP do MWRiOP w sprawie b. cerkwi w Łomży przy pl. Sienkiewicza, 15 XII 1927, s. 151-152. Zob. też: H. Sienkiewicz, Cerkwie w krainie kościołów, Warszawa 2006, s. 159.

${ }^{46}$ AAN, MWRiOP, sygn. 1215, MSW do MWRiOP w sprawie cerkwi prawosławnej w Łomży przekazanej katolickim władzom kościelnym, 24 XII 1927, s. 153.

${ }^{47}$ K. Skłodowski, Stużba duszpasterska..., s. 62-63.

${ }^{48}$ Obok wskazanego pułku były to jeszcze m.in. 2 Pułk Ułanów Grochowskich im. gen. Józefa Dwernickiego oraz 3 Pułk Szwoleżerów Mazowieckich im. płk. Jana Kozietulskiego. 
Rolnictwa i Dóbr Państwowych (MRiDP). Kuria biskupia w Łomży, stojąc na stanowisku niezbywalności obiektu, przychyliła się częściowo do próśb wojskowych. Wyrażono zgodę, aby nabożeństwa przeznaczone specjalnie dla nich były odprawiane w każdą niedzielę i święta o godzinie dziewiątej. Takie rozwiązanie nie satysfakcjonowało jednak dowództwa, któremu zależało na korzystaniu ze świątyni na wyłączność. Pod adresem kleru padały oskarżenia m.in. o szkalowanie wojska w kazaniach, demonstracyjne odsuwanie się księży podczas uroczystości państwowych, uniemożliwianie pracy nad podniesieniem stanu moralnego żołnierzy czy wynajmowanie osobom postronnym pomieszczeń na plebanii ${ }^{49}$. Duchowni z kolei argumentowali, że wojsko zmieniło ustalona wcześniej godzinę mszy, zakłócając nabożeństwa odprawiane dla ludności świeckiej, przez co całkowicie ich zaniechano. Wskazywano ponadto, że garnizon posiadał też inną cerkiew (św. Jerzego), która mógł przebudować na kościół, zagospodarował ją jednak na magazyn. Odwoływano się też do sytuacji, w której kapelan suwalskiego garnizonu, ks. Dominik Amankowicz publicznie obraził ks. rektora Bronisława Tałandziewicza. Kolejne spory wyniknęły na tle użytkowania przykościelnego ogrodu oraz cmentarza wojskowego ${ }^{50}$.

Ostatecznie biskup łomżyński Romuald Jałbrzykowski, zażegnując konflikt, zgodził się na oddanie kościoła wraz z dwoma przynależnymi budynkami dla potrzeb garnizonu, w zamian uzyskujacc ekwiwalent w postaci budynku do rozbiórki na terenie koszar ${ }^{51}$. Do komisyjnego przekazania świątyni doszło 3 III 1924 r., a cztery lata później, 29 września odbyła się jej uroczysta konsekracja, dokonana przez biskupa polowego Wojska Polskiego Stanisława Galla. Przy dawnej cerkwi, w pierwszej połowie 1926 r., utworzono parafię wojskowa św. Kazimierza, która objęła swym zasięgiem powiaty suwalski i augustowski ${ }^{52}$. Świątynią garnizonowa - również zaadaptowana z prawosławnej cerkwi (św. Mikołaja) i stanowiąca placówkę filialną suwalskiej parafii - był kościół Matki Boskiej Częstochowskiej na terenie koszar w Augustowie. Jego konsekracja miała miejsce dopiero w 1927 r., choć należy domniemywać, że podobnie jak w Suwałkach nabożeństwa odbywały się już wcześniej. Tak późne poświęcenie obiektu było spowodowane najpewniej dużym stopniem dewastacji kompleksu koszarowego, przez co skierowany tu 1 Pułk Ułanów Krechowieckich stacjonował $\mathrm{w}$ początkowym okresie w okolicznych miejscowościach ${ }^{53}$.

${ }^{49}$ AAN, MWRiOP, sygn. 1220, MSW do MWRiOP w sprawie przydziału kościoła dla garnizonu w Suwałkach, grudzień 1922, s. 297; K. Skłodowski, Stużba duszpasterska..., s. 64-65.

${ }^{50}$ K. Skłodowski, Stużba duszpasterska..., s. 64; AAN, MWRiOP, sygn. 1220, Proboszcz parafii św. Aleksandra w Suwałkach ks. S. Szczęsnowicz do ks. biskupa w Łomży w sprawie byłej cerkwi pułków piechoty rosyjskiej, 16 I 1922, s. 288-292.

51 AAN, MWRiOP, sygn. 1220, MSW do DOK III w Grodnie w sprawie kościoła garnizonowego w Suwałkach, 12 II 1922, s. 278.

${ }^{52}$ K. Skłodowski, Stużba duszpasterska..., s. 65.

${ }^{53}$ J. Szlaszyński, 1. Putk Ułanów Krechowieckich w Augustowie, „Rocznik Augustowsko-Suwalski” 2006, t. VI, s. 91, 93. 


\section{Cerkwie w dobrach katolickiego duszpasterstwa diecezjalnego}

Ucząca się młodzież w szkołach powszechnych i gimnazjach, a także studenci przygotowujący się do stanu kapłańskiego byli drugą po żołnierzach grupa, dla której - w związku z niewielką liczbą kościołów i ich przepełnieniem - zabiegano o powstanie osobnych świątyń. Starania w tym kierunku odniosły sukces w Suwałkach, gdzie utrzymano w mocy decyzje niemieckich władz wojskowych, nadając byłemu soborowi wezwanie Najświętszego Serca Pana Jezusa. Do dyspozycji prefekta ks. Jerzego Rogińskiego i sasiadującego z kościołem gimnazjum władze państwowe przekazały także w dzierżawę budynki byłej prawosławnej plebanii oraz niewielki przycerkiewny ogród.

$\mathrm{Na}$ pewne trudności natrafiła natomiast kuria biskupia w Łomży podczas przejmowania kościoła garnizonowego (byłego soboru). Decyzję MSW zakwestionowały bowiem Ministerstwo Robót Publicznych (MRP), sprawujące zarząd państwowy nad mieniem cerkiewnym, oraz $\mathrm{MWRiOP}^{54}$. Obie instytucje podkreślały samowolność władz wojskowych i niemożność podjęcia takich kroków bez ich zgody do czasu powstania odpowiednich uregulowań ustawodawczych ${ }^{55}$. Opór władz znikną jednak całkowicie, gdy okazało się, że poparcie dla sprawy bp Stanisław Łukomski wyjednał u marsz. Józefa Piłsudskiego, który miał stwierdzić, że „To jest bardzo łatwe do zrobienia" ${ }^{6}$. W ten sposób kuria stała się posiadaczem kościoła, jak i wszystkich należących do niego nieruchomości (murowanego domu, drewnianej szopy oraz półhektarowego sadu) ${ }^{57}$.

${ }^{54}$ Zarząd państwowy nad „majątkiem pocerkiewnym oraz stanowiącym uposażenie duchowieństwa prawosławnego” został ustanowiony Dekretem Naczelnika Państwa Józefa Piłsudskiego z dnia 16 grudnia 1918 r. Początkowo miało sprawować go MRiDP, następnie MRP. W związku z uznaniem, co nie było zgodne z rzeczywistościa, że Kościół prawosławny nie posiadał w Imperium Rosyjskim osobowości prawnej, władze polskie traktowały majątki cerkiewne jako własność państwowa. Ich los miał wyjaśnić się z chwilą uregulowania położenia prawnego Kościoła prawosławnego w Polsce, co jednak - w przypadku majątków - nastapiło dopiero w czerwcu 1939 r. Szerzej zob. W. Bendza, Regulacja kościelnych spraw majatkowych na przykładzie Kościoła prawosławnego w Polsce, Warszawa 2009, s. 19-41; M. Papierzyńska-Turek, Między tradycjq a rzeczywistościa. Państwo wobec prawostawia 1918-1939, Warszawa 1989, s. 155-163, 182-193, 323-325.

55 AAN, MWRiOP, sygn. 1215, MWRiOP do MSW w sprawie przekazania przez MSW b. cerkwi przy pl. Sienkiewicza do użytku Kościoła katolickiego, 17 XII 1927, s. 149-150; ibidem, MRP do MWRiOP w sprawie budynku byłej cerkwi w Łomży przy pl. Sienkiewicza, 15 XII 1927, s. 151-152.

${ }^{56}$ Ibidem, Wyciag z listu ks. biskupa łomżyńskiego w sprawie uzyskania zgody marszałka J. Piłsudskiego na przejęcie b. soboru prawosławnego w Łomży, 17 III 1928, s. 168.

${ }^{57}$ Ibidem, sygn. 980, Statystyka ludności... - Łomża, [1919], s. 113-114; ibidem, sygn. 1193, Woj. białostockie, powiat łom. - wykaz ziem cerkiewnych, [1930-1931], s. 106-107; ibidem, sygn. 1201, Wojewoda białostocki do MWRiOP w sprawie nieruchomości pocerkiewnej w Łomży, 5 II 1924, s. 294. 
Na rzecz parafii katedralnej św. Michała Archanioła, w związku z niewielka liczbą prawosławnych mieszkańców, zajęto również kaplicę Grobu Pańskiego w prawosławnej części wielowyznaniowej nekropolii. Najpewniej już w okresie międzywojennym wykorzystywano ją jako kaplicę przedpogrzebową ${ }^{58}$.

\section{„[...] żołnierzowi polskiemu w hołdzie, podzięce i braterskiemu przy- wiązaniu"59 - cerkwie oddane na świeckie potrzeby żołnierzy}

Po zaspokojeniu potrzeb religijnych żołnierzy oraz ludności cywilnej pozostała pewna liczba świątyń, które nie posiadały żadnego przeznaczenia. Należały do nich m.in. cerkiew św. Jerzego w Suwałkach oraz św. Apostołów Piotra i Pawła w Łomży. Pierwsza, jak już wspomniałem, nie wcześniej jak w październiku 1920 r. i nie później jak w lutym roku 1923 r. ${ }^{60}$, zajęto na skład wojskowy. Druga natomiast, wymagająca remontu już w roku 1919, niszczała przez kolejne lata, pozbawiona opieki dawnych właścicieli.

W związku z przekazaniem jej 28 XI 1922 r. przez MSW pod zarząd MRP, jako zbędnej dla wojska ${ }^{61}$, pojawiła się inicjatywa, aby i w Łomży powstał kościół „dla uczącej się młodzieży szkół średnich i powszechnych”62. Występujacy z nia „Komitet Szkolny Rewindykacyjny” postulował jednak, aby do tego celu pozyskać dawny kościół Pijarów św. Stanisława Kostki, który Komisja Rządowa Spraw Wewnętrznych i Duchownych z uwagi na możliwość zawalenia przekazała w $1853 \mathrm{r}$. tutejszej parafii ewangelicko-augsburskiej ${ }^{63}$. Ewangelikom, dla których ów kościół wydawał się zbyt wielki, proponowano zaś zagospodarowanie byłej cerkwi garnizonowej. Do czasu zakończenia pertraktacji świątynia pełniłaby - w zamyśle komitetu - funkcję kościoła dla młodzieży, gdyż „stoi od dawna pustkami [...], i jest przez miejscową ludność

58 D. Godlewska, Plan - informator cmentarza zabytkowego w Łomży, Łomża 1989, s. 7.

${ }^{59}$ Cytat z aktu, którym Komitet Budowy Domu Żołnierza w Łomży przekazał budynek dowództwu garnizonu (14 IX 1930). Zob. Na otwarcie Domu Żotnierza..., s. 18.

${ }^{60}$ AAN, MWRiOP, sygn. 1061, Starostwo Powiatowe w Suwałkach do MWRiOP w sprawie oddania ludności prawosławnej jednej ze świątyń w Suwałkach, 18 X 1920, s. 484; ibidem, UWB do MWRiOP w sprawie parafii prawosławnej w Suwałkach, 24 II 1923, s. 504.

${ }^{61}$ Ibidem, sygn. 1215, MRP do MWRiOP w sprawie oddania byłej cerkwi garnizonowej w Łomży do użytku gminy ewangelicko-augsburskiej, 13 XI 1922, s. 70. Pojawił się pomysł przebudowy świątyni na biura, ale prace przerwano - z niewiadomych przyczyn - na skutek interwencji Ministerstwa Spraw Wewnętrznych. Ibidem, UWB do MWRiOP w sprawie przekazania parafii ewangelicko-augsburskiej w Łomży cerkwi 14 Ołonieckiego Pułku Piechoty w zamian za kościół popijarski, 28 III 1928, s. 84.

${ }^{62}$ Ibidem, MRP do MWRiOP o przekazaniu przez MSW byłej cerkwi garnizonowej w Łomży pod zarząd MRP, 20 II 1923, s. 83.

${ }^{63}$ Ibidem, Konsystorz Ewangelicko-Augsburski do MWRiOP w sprawie starań Komitetu Szkolnego Rewindykacyjnego o przyznania kościoła ewangelickiego w Łomży, 8 I 1923, s. 80. Zob. też: O kościele po-pijarskim w Łomży, „Gazeta Łomżyńska”, 2 I 1921, nr 41, s. 2. 
niemiłosiernie niszczona i rozkradaną" ${ }^{4}$. Na takie rozwiązanie nie zgodził się jednak Konsystorz Ewangelicko-Augsburski w Warszawie, podkreślając, że obiekt wymagałby kosztownych przeróbek i był zbyt daleko oddalony od plebanii. Obawy budził też stan prawny świątyni, która w drodze przyszłej ustawy regulującej sprawy majątków cerkiewnych mogłaby zostać ewangelikom odebrana. Pastor łomżyński ks. Kacper Mikulski domagał się natomiast, aby polski rząd, w zamian za kościół popijarski, wybudował ewangelikom świątynię na tysiąc osób i przekazał dodatkowo budynek mieszkalny z ogrodem ${ }^{65}$.

Żądania te były niemożliwe do spełnienia, przez co sprawa stanęła w martwym punkcie. Mimo zapewnień komitetu o zagospodarowaniu cerkwi na tymczasową kaplicę dla młodzieży również i w tym kierunku niczego nie uczyniono. W związku z tym, na mocy reskryptu MRP z 21 II 1927 r., obiekt został ponownie oddany dowództwu garnizonu łomżyńskiego, które już od dłuższego czasu zabiegało o wykorzystanie go dla potrzeb kulturalno-oświatowych żołnierzy ${ }^{66}$, a dokładniej na Dom Żołnierza. Na realizację tego pomysłu należało czekać jednak kolejne dwa lata. W tym czasie wykonano pewne prace przekształcające wnętrze cerkwi na salę gimnastyczną ${ }^{67}$.

Utworzenie Domu Żołnierza miało być finalnym punktem obchodów 10. rocznicy obrony Łomży przed ofensywą bolszewicką w 1920 r. Organizacji uroczystości podją się specjalnie do tego celu zawiazany komitet na czele z dowódcą 18 Dywizji Piechoty gen. Czesławem Młot-Fijałkowskim. Do współpracy zaproszono przedstawicieli władz samorządowych, państwowych i duchownych. Postulowano, aby w placówce znalazły się kino, sala teatralna, czytelnia i gospoda. W planach komitetu miało to być miejsce rozrywek żołnierzy oraz ich spotkań z mieszkańcami miasta. Pod budowę jednogłośnie wybrano „mury po okupantach, stojące u zbiegu Aleji Legjonów i ul. Polowej. Omawiane ruiny zniszczone wpływami atmosferycznymi i ludzkim zapomnieniem - zawalone gruzem i zaśmiecone, przykry sprawiały widok w śródmieściu Łomży”68.

${ }^{64}$ AAN, MWRiOP, sygn. 1215, Podanie Komitetu Szkolnego Rewindykacyjnego w Łomży do MWRiOP w sprawie przekazania mu byłej cerkwi garnizonowej, 26 XII 1922, s. 76.

${ }^{65} \mathrm{O}$ potrzebie tak wielkiego kościoła ks. Mikulski pisał w związku z wizja przyłączenia „mazurów pruskich polaków - ewangelików do naszej Ojczyzny [...]”. Ibidem, Pastor parafii ewangelicko-augsburskiej w Łomży do Komisji Rewindykacyjnej w starostwie powiatowym w Łomży - warunki zwrotu kościoła popijarskiego, 28 VI 1922, s. 100.

${ }^{66}$ Ibidem, MRP do MWRiOP w sprawie przekazania budynku pocerkiewnego w Łomży przy ul. Polowej władzom wojskowym, 4 VIII 1924, s. 87; Archiwum Diecezjalne w Łomży (dalej: ADŁ), Akta parafialne z okresu międzywojennego - Łomża, sygn. 46, Starostwo powiatowe w Łomży do kurii biskupiej w sprawie przekazania byłej cerkwi przy ul. Polowej władzom wojskowym, k. 38.

${ }_{67}$ Sportowiec, Po sezonie sportowym, „Wspólna Praca” 1927, nr 8, s. 12. Zob. też: AAN, MWRiOP, sygn. 1206, UWB do MWRiOP w sprawie wykazu świątyń prawosławnych na terenie części powiatów województwa i b. cerkwi wojskowej w Łomży, 5 XI 1928, s. 50.

${ }^{68}$ Na otwarcie Domu Żołnierza..., s. 8. W publikacji ani razu nie padło stwierdzenie, że owe „ruiny” były pozostałościami po świątyni prawosławnej. 
Liczne ofiary, subsydia wyasygnowane przez m.in. sejmik powiatowy i magistrat oraz sprzedane cegiełki przyniosły kwotę blisko 65 tys. zł, dzięki czemu zaplanowane prace zostały wykonane w terminie. W obecności wielu oficjeli $\mathrm{w}$ podniosłej atmosferze dom otwarto 13 IX $1930 \mathrm{r}^{69}$

\section{„[...] nasza ziemia, co my chcemy, to i robimy"70 - cerkwie rozebrane}

Inny stosunek, niż do świątyni łomżyńskiej, miały władze lokalne do cerkwi św. Apostołów Piotra i Pawła w Augustowie ${ }^{71}$. Mimo iż wkrótce po wojnie jej stan techniczny przedstawiano jako dobry, w połowie lat dwudziestych podjęto wiele wysiłków zmierzających do jej rozbiórki. Postanowiono, aby do celów kulturalnych przeznaczona została nie sama cerkiew, ale nowy budynek, który planowano wznieść w innym miejscu z cerkiewnego materiału rozbiórkowego. $\mathrm{Na}$ posiedzeniu sejmiku powiatowego $21 \mathrm{X} 1924 \mathrm{r}$. uchwalono, że będą to zakłady dobroczynne wraz ze szkoła zawodowa, których budowa pokierować miał Powiatowy Komitet Opieki Społecznej wespół ze Zgromadzeniem Sióstr Franciszkanek Rodziny Maryi. Na ich lokalizację wybrano plac na rogu ulic Hożej i Młyńskiej, przekazany przez MRiDP, który przed wojną również należał do Kościoła prawosławnego (była to działka sassiadująca od południa z cerkwią Kazańskiej Ikony Matki Bożej, nad rzeką Netta) ${ }^{72}$.

W ciagu kilku lat okazało się, że cerkiew znajdowała się w stanie ruiny, nie miała dachu i okien, a ,z powodu przegniłego wiązania stropowego i zaciekania, oraz innych defektów zagraża bezpieczeństwu publicznemu"73. Powoływano się przy tym na przypadek zerwania się znacznych rozmiarów krzyża $\mathrm{z}$ wieży cerkiewnej, obawiając się, że podobne zdarzenia będą miały miejsce w przyszłości. W tym kontekście poruszano kwestię usytuowania obiektu centralnego punktu rynku, na którym odbywały się targi i jarmarki. Władze miejskie podkreślały, że jest to „najlepszy punkt” miasta, a wzniesienie cerkwi „nastapiło wbrew woli mieszkańców i było przejawem gwałtu ciemiężców

${ }^{69}$ Ibidem, s. 13, 15-17. Na temat pracy komitetu (posiedzenia z zebrań) zob. też: AD£, Akta parafialne z okresu międzywojennego - Łomża, sygn. 46, k. 121-125.

70 Taką odpowiedź miał usłyszeć proboszcz prawosławny z Suwałk od wicestarosty powiatu augustowskiego, protestując przeciwko rozbiórce cerkwi św. Apostołów Piotra i Pawła w Augustowie. Пріъзжій, Корреспондениіи. Из Августова, „Воскресное Чтеніе”, 12 IX 1926, № 37, s. 586.

${ }^{71}$ Według Sokoła i Sosny świątynia w 1921 r. została zajęta tymczasowo na kościół garnizonowy 1 Pułku Ułanów Krechowieckich. Autorzy nie powołali się jednak na źródło swej informacji, a nie udało się potwierdzić jej na podstawie dostępnych opracowań oraz materiałów archiwalnych. K. Sokoł, A. Sosna, op. cit., s. 34.

72 AAN, MWRiOP, sygn. 1208, Wyciąg z protokołu posiedzenia sejmiku powiatowego w dn. 21 X 1924 w Augustowie, s. 293-294.

${ }^{73}$ Ibidem, UWB do MWRiOP w sprawie odprawiania nabożeństw przez duchownego prawosławnego w cerkwi w Augustowie, 9 XII 1925, s. 291-292. 
nad uczuciami patriotycznymi i religijnemi polskiej ludności i jest symbolem widomym niewoli minionej"74. Ów plac w latach osiemdziesiąych XIX w. miał być odebrany magistratowi pod przymusem, bez wypłacenia jakiejkolwiek rekompensaty ${ }^{75}$. Argumentowano również, że w Augustowie mieszkało jedynie ok. 80 osób wyznania prawosławnego (w tym grupa internowanych kozaków przebywających tu tylko tymczasowo ${ }^{76}$ i cerkiew była im zbędna.

Uchwała sejmiku powiatowego uzyskała poparcie Rady Miejskiej Augustowa (na 16 radnych „za” było 13, 1 wstrzymał się od głosu), MRP, MWRiOP, a także działającego przy Radzie Ministrów Komitetu Politycznego do Spraw Województw Wschodnich i Mniejszości Narodowych ${ }^{77}$. W związku z tym na początku 1926 r. powzięto decyzję o rozbiórce, a w pierwszych dniach kwietnia rozpoczęto prace ${ }^{78}$. Dopiero wtedy poinformowano o tym, opiekującego się wiernymi w Augustowie, ks. Antoniego Marcinkiewicza z Suwałk, proszacc, aby „obrazy święte i inne utensylja cerkiewne” zostały pilnie zabrane z budynku ${ }^{79}$. Warto zaznaczyć, że wcześniej księdzu odmówiono odprawiania nabożeństw w cerkwi ${ }^{80}$. Władze wojewódzkie negatywnie zaopiniowały też prośbę biskupa grodzieńsko-nowogródzkiego Aleksego o możliwość wyremontowania świątyni ${ }^{81}$.

Dopiero po interwencji Marcinkiewicza o sprawie dowiedział się metropolita Dionizy, stanowczo protestując przeciwko likwidacji obiektu i zapewniając, że był on niezbędny dla prawosławnej ludności Augustowa oraz sporej liczby kwaterujących tam żołnierzy ${ }^{82}$. Wskazywał też, że takie działania - wobec

${ }^{74}$ Ibidem, Wyciag z protokołu posiedzenia rady miejskiej w Augustowie w dniu 19 XII 1925, s. $297-298$.

${ }^{75}$ Ibidem, Wniosek MRP w sprawie rozbiórki cerkwi prawosławnej stojącej bez użytku na rynku w Augustowie, [1925], s. 302-303.

${ }^{76}$ Ibidem, Wyciag z protokołu posiedzenia rady miejskiej..., s. 297-298. Według spisów ludności przeprowadzonych w 1921 i 1931 r. było to odpowiednio 90 i 171 osób. J. Szlaszyński, Od pierwszej do drugiej..., s. 374.

$77 \mathrm{~W}$ zamian za to inicjatorzy rozbiórki zobowiązywali się do przeniesienia na cmentarz niemieckich grobów wojennych znajdujących się przy cerkwi. AAN, MWRiOP, sygn. 1208, Wniosek MRP w sprawie rozbiórki cerkwi prawosławnej stojącej bez użytku na rynku w Augustowie, [1925], s. 302-303; Кь разборкг православнаго храма вг Августовґ, „Воскресное Чтеніе”, 16 I 1927, № 3, s. 24.

78 Cerkiew została rozebrana najpewniej na podstawie przepisów budowlanych, które dopuszczały taką możliwość - po komisyjnych oględzinach obiektu, szacunkowej wycenie materiału rozbiórkowego i wyroku sądowym - w wypadku, gdy jej stan techniczny zagrażał bezpieczeństwu publicznemu. P. Zubowski, Cerkwie prawosławne Łodzi i regionu tódzkiego $w$ dwudziestoleciu międzywojennym (1918-1939), Białystok 2014, s. 48-49.

79 AAN, MWRiOP, sygn. 1208, Metropolita Dionizy do MWRiOP z prośbą o odwołanie decyzji dotyczącej rozbiórki cerkwi w Augustowie, 20 V 1926, s. 305.

${ }^{80}$ Po wojnie nabożeństwa odbywały się okazjonalnie. Ostatnie odprawił Marcinkiewicz w święta Wielkiejnocy w 1924 r. Пріњзжій, op. cit., s. 586.

${ }^{81}$ AAN, MWRiOP, sygn. 1208, UWB do MWRiOP w sprawie odprawiania nabożeństw przez duchownego z Suwałk w cerkwi w Augustowie, 9 XII 1925, s. 291.

82 Według zebranych danych w garnizonie w Augustowie stacjonowało 25 żołnierzy wyznania prawosławnego w 1924 r., 17 - w 1925 r., 122 szeregowych i 1 oficer w 1927 r., 90 szeregowych 
finalizowania rozmów dotyczących ustalenia statutu Kościoła prawosławnego w Polsce - były kategorycznie niedopuszczalne. Według doniesień prasy prawosławnej na przystapienie do demontażu cerkwi oburzyli się też augustowscy Żydzi oraz większość Polaków ${ }^{83}$.

Wstrzymanie prac - zarządzone na wniosek ministra spraw wewnętrznych Kazimierza Młodzianowskiego, który rozbiórkę uważał za bezzasadna, dająca powody prawosławnym do agitacji przeciwko rządowi - na niewiele się zdało. Z zachowanych źródeł wiadomo bowiem, że przeciwko tej decyzji opowiedziało się MWRiOP. Wydano ją też zbyt późno, gdyż 17 czerwca z cerkwi pozostały jedynie fundamenty, gruz i cegły, zlikwidowano natomiast całkowicie sąsiadująca ze świątynią stróżówkę oraz ogrodzenie ${ }^{84}$. Okoliczności rozbiórki następująco wspominał starosta powiatu augustowskiego Wacław Malanowski:

Wymieniona sprawa była rozpatrywana przez Radę Ministrów i uzyskała aprobatę. Po paru miesiącach oczekiwania został mi przysłany przez Urząd Wojewódzki Białostocki dekret Ministra Robót Publicznych Barlickiego, zezwalający na rozbiórkę. Zarządziłem tedy natychmiastowe roboty - obawiałem się bowiem iżby na skutek zabiegów wyższego kleru prawosławnego wydane zezwolenie nie zostało wstrzymane lub nawet cofnięte. Jakoś kiedy już został zdjęty dach i rozbite stropy nadszedł z Województwa telefonogram z zapytaniem na jakiej podstawie i z czyjego rozporzadzenia jest dokonywana rozbiórka cerkwi. Odpowiedziawszy, że na mocy dekretu Min. Robót Publ. Nadesłanego mi przez Urząd Wojewódzki, kazałem dzień i noc rozbierać cerkiew, a to w obawie iżby zaczęte dzieło nie zostało w połowie sparaliżowane. Przewidywania moje okazały się słuszne za parę dni bowiem nadszedł telegraficzny rozkaz wstrzymania rozbiórki a w ślad za tym utrzymane w niesłychanie aroganckim i gwałtownym tonie pismo biskupa prawosławnego z Grodna Aleksego, domagające się natychmiastowego przerwania robót burzycielskich. W tym stanie rzeczy kazałem potroić liczbę robotników, a doprowadziwszy rozbiórkę do fundamentów, wezwałem fotografa i odpowiednie zdjęcie przedstawiajace już tylko fundamenty i ułożoną w kozły cegłę - posłałem Urzędowi Wojew. wraz z pismem, że wobec faktu dokonanego rozkaz dotyczący wstrzymania rozbiórki jest już nieaktualny. W taki to sposób starłem z Augustowa nadane mu sztucznie piętno prawosławia a właściwie „carosławia” ${ }^{85}$.

w 1932 r., 140 szeregowych i 1 oficer w 1938 r. Centralne Archiwum Wojskowe (dalej: CAW), Biuro Wyznań Niekatolickich (dalej: BWN), sygn. I.300.20.58, Sumaryczny wykaz osób wojskowych wyznania prawosławnego w DOK III - stan na 1.01.1925, 15 II 1927, k. nlb.; ibidem, sygn. I.300.20.57, DOK III Szefostwo Duszpasterstwa Wyznania Prawosławnego do Głównego Wojskowego Urzędu Duszpasterstwa dla Wyznania Prawosławnego w sprawie żołnierzy wyznania prawosławnego w Augustowie, 28 I 1924, k. 59; ibidem, Sprawozdanie z działalności dziekanatu prawosławnego OK III za rok 1932, 1938, k. 216, 280.

${ }^{83}$ Пріњзжій, op. cit., s. 586. Z kolei władze wojewódzkie w Białymstoku pisały, że „Przystąpienie do rozbiórki cerkwi cała ludność polska przyjęła z rzetelnym uznaniem i radościa - uważając jej usunięcie za akt sprawiedliwości i zadośćuczynienia dla tak długo gnębionej i poniewieranej przez najeźdźców polskości”. AAN, MWRiOP, sygn. 1208, Wojewoda białostocki do MWRiOP w sprawie rozbiórki cerkwi w Augustowie, 13 VII 1926, s. 320.

${ }^{84}$ Ibidem, Protokół z komisyjnych oględzin placu pocerkiewnego w Augustowie, 17 VI 1926, s. 322.

${ }^{85}$ Muzeum Ziemi Augustowskiej w Augustowie, „Wacław Malanowski: Wspomnienia” (kopia maszynopisu ze zbiorów rodziny Ścisłowskich z Poznania), materiały nieinwentaryzowane, 
Cały materiał rozbiórkowy oraz niektóre elementy zachowanego wyposażenia (m.in. piece) sprzedano najpewniej w drodze licytacji, a uzyskane fundusze (616 zł) wpłacono do kasy skarbowej w Augustowie na konto MRP ${ }^{86}$.

\section{Próby utworzenia parafii prawosławnych przy cerkwiach}

Spadek liczby wiernych wyznania prawosławnego na opisywanym terenie okazał się najmniej odczuwalny w jego północnej części. Według statystyk prowadzonych przez władze wojewódzkie w Białymstoku, w 1923 r. w powiecie suwalskim i sejneńskim oraz osadzie Raczki w powiecie augustowskim mieszkało łącznie 1612 osób tego wyznania ${ }^{87}$. Taka liczba spowodowała, że wśród wszystkich przedwojennych parafii guberni suwalskiej i łomżyńskiej MWRiOP wyraziło zgodę, aby tylko ta znajdująca się w Suwałkach wznowiła swoją działalność. Na jej duszpasterza wyznaczono wspomnianego wyżej ks. A. Marcinkiewicza, który już przed wojną posługiwał przy soborze Zaśnięcia Najświętszej Maryi Panny, a w listopadzie 1914 r. otrzymał święcenia kapłańskie ${ }^{88}$. Starosta suwalski pisał o nim, że „jest to staruszek «baciuszka» nie mogący się pogodzić ze zmiennem szczęściem powstania Polski; nie zauważono jednak żadnych wystapień jego przeciwko państwowości polskiej”89.

s. 17. Za udostępnienie wspomnień serdecznie dziękuję kustoszowi augustowskiego muzeum p. Wojciechowi Baturze.

${ }^{86}$ AAN, MWRiOP, sygn. 1184, UWB do MWRiOP w sprawie odbudowy zrujnowanej cerkwi nad Kanałem w Augustowie, 4 XII 1933, s. 6. Na działce, na której planowano wznieść szkołę zawodową i zakłady dobroczynne, w latach 1928-1931 postawiono gmach Szkoły Powszechnej im. Marszałka Józefa Piłsudskiego. Według bpa Aleksego do budowy został wykorzystany materiał rozbiórkowy z cerkwi św. Apostołów Piotra i Pawła. Ibidem, sygn. 1208, Biskup grodzieńsko-nowogródzki Aleksy do wojewody w Białymstoku z prośba o wyremontowanie cerkwi Kazańskiej Ikony Matki Bożej w Augustowie, 20 XII 1927, s. 356. Sokoł i Sosna stwierdzili, że posłużył on do budowy gimnazjum (w latach 19261927), w którym - w związku z brakiem odpowiedniej kadry pedagogicznej - znalazło się Państwowe Seminarium Nauczycielskie Męskie im. Grzegorza Piramowicza. K. Sokoł, A. Sosna, op. cit., s. 34 .

${ }^{87} \mathrm{Na}$ tę liczbę składali się przede wszystkim mieszkańcy Suwałk (950 osób) i Karolina (512 osób). AAN, MWRiOP, sygn. 1061, UWB do MWRiOP w sprawie parafii prawosławnej w Suwałkach, 24 II 1923, s. 504. W Karolinie (Pokrowsku) przed wojną istniała parafia jednowierców (staroobrzędowców, którzy przystapili do unii z Rosyjskim Kościołem Prawosławnym) posiadająca cerkiew Opieki Matki Bożej. Po 1918 r. działalności parafii nie wznowiono, przyłączajac wiernych do parafii w Suwałkach. Cerkiew, po przebudowie, została wyświęcona na kościół Świętej Rodziny. Na ten temat zob. dokumentację komitetu budowy kościoła w Karolinie: APB, UWB, sygn. 280, k. 1-9.

${ }^{88}$ Biogram A. Marcinkiewicza zob. G. Sosna, A. Troc-Sosna, Hierarchia i kler Kościoła prawostawnego w granicach II Rzeczypospolitej i Polski powojennej w XIX-XXI wieku, Ryboły 2012 , s. $542-543$.

${ }^{89}$ AAN, MWRiOP, sygn. 1220, Starosta powiatowy w Suwałkach do MWRiOP - opinia o ks. A. Marcinkiewiczu, 21 XII 1920, s. 266. 
Warunki, w których przyszło działać parafii - w stosunku do realiów przedwojennych - przedstawiały się nader skromnie. Cały dotychczas użytkowany majątek (świątynie, grunty, budynki mieszkalne i gospodarcze), podobnie jak w innych miastach, został zajęty przez władze państwowe ${ }^{90}$. Jedynym obiektem sakralnym, który pozostawiono wiernym, była niewielka drewniana cerkiew Wszystkich Świętych na cmentarzu prawosławnym, znajdująca się w znacznej odległości od centrum ${ }^{91}$. Podjęte starania o zwrot byłego soboru, wobec zamiany go na kościół gimnazjalny, nie przyniosły żadnego skutku. $\mathrm{Z}$ zachowanego materiału źródłowego wiadomo, że władze planowały przekazanie parafii cerkwi wojskowej św. Jerzego, jednak miała ona być w tak dużym stopniu dewastacji, że wierni, nie posiadając odpowiednich środków, odmówili jej przejęcia i doprowadzenia do stanu używalności ${ }^{92}$.

W bardzo trudnej sytuacji materialnej znalazł się sam Marcinkiewicz. Parafia utraciła ok. 16-20-morgowy grunt określany jako „Popowizna”, wydzierżawiony przez władze rządowe osobom prywatnym ${ }^{93}$. Na potrzeby gimnazjum przejęty został budynek plebanii, w związku z czym proboszcz, podobnie jak jego następcy, zmuszony był do wynajmowania mieszkania ${ }^{94}$. Uposażenie, które otrzymywał jako zwierzchnik placówki etatowej, musiało nie wystarczać, skoro według władz wojewódzkich miał on „ustawicznie utyskiwać na ciężkie położenie materialne” i „żebrać po urzędach pierwszego każdego miesiąca" ${ }^{95}$.

Sytuacja finansowa Marcinkiewicza w pewnym stopniu poprawiła się, gdy przyją dodatkowo obowiązki kapelana pomocniczego żołnierzy prawosławnych z suwalskiego garnizonu ${ }^{96}$. Wspólne nabożeństwa dla wojskowych i cywilów

90 Stało się tak na mocy dekretu o przymusowym zarządzie mienia pocerkiewnego (zob. przypis 54) rozciagniętego na zachodnie powiaty województwa białostockiego w $1923 \mathrm{r}$. AAN, Ministerstwo Rolnictwa i Reform Rolnych (dalej: MRiRR), sygn. 252, Wykaz majątków pocerkiewnych powiatów: augustowskiego, sejneńskiego, suwalskiego, łomżyńskiego, kolneńskiego, wysoko-mazowieckiego, ostrołęckiego i ostrowskiego, kwiecień 1923, k. 47-54.

${ }_{91}$ Poza cmentarzem suwalskim parafia zarządzała nekropoliami prawosławnymi w Karolinie, Augustowie i Raczkach.

92 AAN, MWRiOP, sygn. 1061, MRiDP do MWRiOP w sprawie cerkwi garnizonowej przy rogatce sejneńskiej w Suwałkach, 22 XI 1920, s. 500; S. Borowik, op. cit., s. 25.

${ }^{93}$ AAN, MRiRR, sygn. 252, Wykaz majątków... - pow. suwalski, k. 52-53; AAN, MWRiOP, sygn. 1061, MWRiOP do MRiDP w sprawie gruntów pocerkiewnych w Suwałkach, 26 IV 1923, s. 502; ibidem, MRiDP do MWRiOP o oddaniu do użytku parafii prawosławnej osady „Popowizna”, 5 VII 1923, s. 510.

${ }^{94}$ AAN, MWRiOP, sygn. 1202, Podanie proboszcza parafii prawosławnej w Suwałkach ks. Włodzimierza Żeromskiego do UWB o wybudowanie plebanii prawosławnej i pokrycie kosztów wynajmu mieszkań dla proboszcza i psalmisty, $16 \mathrm{~V} \mathrm{1938,} \mathrm{s.} 450$.

${ }_{95}$ Od 1 IV 1920 r. Marcinkiewicz otrzymywał uposażenie w wysokości 500 marek miesięcznie. Ibidem, sygn. 1061, MWRiOP do MRiDP o utworzeniu tymczasowej parafii prawosławnej w Suwałkach, 29 X 1920, s. 493.

96 Kapelanem pomocniczym został nie później jak w marcu 1923 r. W 1925 r. w suwalskim garnizonie stacjonowało 229 żołnierzy wyznania prawosławnego. Ustalono też dane dla 
w cmentarnej cerkwi wymogły potrzebę zapewnienia większego obiektu, gdyż wielu z nich musiało modlić się poza świątynia. W związku z tym ponownie poruszono sprawę cerkwi św. Jerzego, w której garnizon urządził magazyn broni. O przekazanie jej prawosławnym zabiegali zarówno suwalski starosta, wojewoda białostocki, jak i MWRiOP. Ostatecznie też, kierując się liczbą żołnierzy, swoją zgodę wyraziło $\mathrm{MSW}^{97}$. Na początku 1924 r. parafii zwrócono też całość lub większą część majątku „Popowizna”98.

Mimo iż władze popierały utworzenie w Suwałkach parafii wojskowej, najpewniej nie przyczyniły się istotnie do odrestaurowania świątyni. W relacji Marcinkiewicza, na która powołuje się Borowik, miała ona wybite okna, połamane drzwi, a wnętrze było zasypane śmieciami i gruzem. Dowództwo garnizonu zgodziło się jedynie na postawienie ogrodzenia wokół świątyni, jednak z materiałów, które dostarczą wierni. Zmusiło to parafię do zaciągnięcia pożyczki i sprzedaży części cmentarza, z czego łącznie uzyskano kwotę 3 tys. zł. Prace remontowe zakończyły się po dwóch latach, pod koniec 1925 r., a 6 grudnia cerkiew poświęcił bp Aleksy ${ }^{99}$. Do wyposażenia budynku władze wojskowe planowały przekazać jeden z bocznych ołtarzy zachowanych z cerkwi św. Aleksandra Newskiego za rogatka augustowską ${ }^{100}$.

W późniejszych latach parafia starała się jeszcze o zwrot lub rekompensatę za dzwon z byłego soboru, który prawosławni wierni mieli ufundować niegdyśs z zebranych przez siebie składek. Z uwagi jednak na obawy, że demontaż dzwonu może doprowadzić do zrujnowania wieży, jak też na brak funduszy i przypuszczenia, że przychylenie się do prośby doprowadzi do kolejnych roszczeń, uzyskano najpewniej odpowiedź odmowna ${ }^{101}$. Podobnie było z obietnica wybudowania nowej plebanii jako odszkodowania za nieruchomości utracone przez prawosławnych w Suwałkach. Mimo że jeszcze w 1928 r. miał powstać

późniejszych lat: w 1927 r. było to 3 oficerów i 508 szeregowych, w 1932 r. - 428 żołnierzy, a w 1938 r. - 454. CAW, BWN, sygn. I.300.20.57, Sprawozdanie z działalności Dziekanatu Prawosławnego OK III za rok 1932, 1938, k. 216, 280; ibidem, sygn. I.300.20.58, Sumaryczny wykaz osób wojskowych wyznania prawosławnego w DOK III - stan na 1 I 1925, 15 II 1927, k. nlb.

97 AAN, MWRiOP, sygn. 1061, Wydział Wyznań Niekatolickich przy MSW do MWRiOP o oddaniu byłej cerkwi Huzarów Pawłogrodzkich do użytku parafii prawosławnej w Suwałkach, 22 VI 1923, s. 509.

${ }^{98}$ Ibidem, MRiDP do MWRiOP o oddaniu do użytku parafii prawosławnej osady „Popowizna”, 5 VII 1923, s. 510; ibidem, sygn. 1193, Województwo białostockie, powiat suwalski - wykaz ziem cerkiewnych, [1930-1931], s. 114-115.

99 S. Borowik, op. cit., s. 26.

${ }^{100}$ CAW, BWN, sygn. I.300.20.90, DOK III Szefostwo Duszpasterstwa Prawosławnego do Wydziału Wyznań Niekatolickich MSW w sprawie wyposażenia byłej cerkwi wojskowej w Suwałkach, 23 VII 1923, k. nlb.

101 AAN, MWRiOP, sygn. 1225, Sprawa dzwonu z byłego soboru w Suwałkach, 1928-1929, s. 205-211. 
kosztorys prac budowlanych, do końca okresu międzywojennego nie poczyniono żadnych kroków w kierunku ich realizacji ${ }^{102}$.

$\mathrm{Na}$ opisywanym terenie, w podobnym czasie co w Suwałkach, powstała druga wojskowa placówka. Na podstawie rozporządzenia MRP z 24 XII 1924 r. utworzono ją w Łomży, oddając do użytku prawosławnych żołnierzy rosyjska wojskową nekropolię w południowej części miasta wraz ze znajdującą się na niej kaplica. W późniejszym czasie odremontowano ją i wyposażono w brakujące naczynia liturgiczne ${ }^{103}$.

Mimo iż w projektach sieci parafialnej na terenie diecezji grodzieńsko-nowogródzkiej ani razu nie pojawił się zapis o parafii lub filii w Augustowie ${ }^{104}$, jeszcze przed końcem 1923 r. bp Aleksy ubiegał się o ich utworzenie. W tym celu wysłał nawet ks. Kalistrata Jarmołowicza, który obok opieki nad wiernymi miał objać stanowisko kapelana pomocniczego prawosławnych żołnierzy ${ }^{105}$. Podobnie jak w przypadku innych świątyń, które pozostawały zamknięte po 1918 r., argumentował: „многіе въ 1914 году не исполняли христіанскаго долга, дъти растутъ некрещенными, брачущіеся живуть безъ вънца, люди умирають безъ напутствія и хрисіанскаго погребенія, дьти и отроки дошли уже безъ всякаго понятія о вђрђ и молитвђ до школьнаго возраста, юношество - въ сплошномъ безбожіи и хулиганствђ проводитъ свои лучшіе годы жизни” ${ }^{106}$.

${ }^{102}$ Ibidem, sygn. 1202, Starosta powiatowy w Suwałkach do UWB w sprawie budowy plebanii prawosławnej i zwrotu kosztów wynajmu mieszkań dla proboszcza prawosławnego i psalmisty, 1 VII 1938, s. 454.

${ }^{103}$ Kaplica znajdowała się $\mathrm{w}$ dobrym stanie, konserwacji wymagał parkan, a wymiany brama. Żołnierze przejęli także stojący na cmentarzu drewniany domek mieszkalny kryty gontem. Ibidem, sygn. 1215, MRP do MWRiOP w sprawie przekazania b. cerkwi garnizonowej na „dom żołnierza”, 9 III 1925, s. 106; CAW, BWN, sygn. I.300.20.90, DOK I Szefostwo Duszpasterstwa Wyznania Prawosławnego do Głównego Urzędu Wojskowego Duszpasterskiego dla Wyznania Prawosławnego w Warszawie w sprawie prawosławnej garnizonowej kaplicy i cmentarza w Łomży, 25 II 1925, k. nlb.; ibidem, Protokół z oględzin prawosławnego cmentarza wojskowego i kaplicy w Łomży, 26 I 1925, k. nlb. W Łomży w 1928 r. stacjonowało 297 żołnierzy wyznania prawosławnego, w $1931 \mathrm{r}$. - 130, w 1932 r. - 207 szeregowych i 2 oficerów. Ibidem, sygn. I.300.20.58, Statystyka żołnierzy wyznania prawosławnego na terenie OK I w 1928 r., k. nlb.; ibidem, sygn. I.300.20.57, Sprawozdanie z działalności Dziekanatu Prawosławnego OK I za 1931 i 1932 r., k. 198, 207-208.

${ }^{104}$ W wykazach występowała jedynie parafia w Suwałkach, w 1937 r. pojawił się też zapis o filii parafii w Lipsku w powiecie augustowskim (nie powstała). AAN, MWRiOP, sygn. 1038, Wykaz parafii prawosławnych w woj. białostockim diecezji grodzieńsko-nowogródzkiej, 1924, s. 55; ibidem, sygn. 1049, Wykaz parafii i filii etatowych i nieetatowych oraz etatów duchowieństwa diecezji grodzieńskiej, 1937, s. 207.

${ }^{105}$ Biogram K. Jarmołowicza zob. G. Sosna, A. Troc-Sosna, Hierarchia i kler..., s. 332333.

${ }^{106}$ CAW, BWN, sygn. I.300.20.57, Biskup grodzieńsko-nowogródzki Aleksy do Szefa Głównego Urzędu Duszpasterstwa Prawosławnego przy MSW w sprawie utworzenia parafii w Augustowie, 5 I 1924, k. 60. 
Przy tym liczba prawosławnych podawana przez biskupa (ok. 500 osób) $\mathrm{w}$ dużym stopniu przewyższała stan faktyczny ${ }^{107}$.

Choć władze wojewódzkie i rządowe negatywnie ustosunkowały się do propozycji hierarchy, dając temu wyraz w rozbiórce cerkwi św. Apostołów Piotra i Pawła, podejmowano dalsze próby utworzenia parafii - tym razem związane ze świątynią Kazańskiej Ikony Matki Bożej. Zabiegi te poparł augustowski starosta, który uważał, że choć prawosławni tworzyli niewielka społeczność, to jednak zasługiwali na miejsce do modlitwy. Oddanie im cerkwi miało być - w związku z przejęciem całego majątku - aktem sprawiedliwości i tolerancji ze strony władz wobec obywateli Rzeczypospolitej, bez zważania na ich wyznanie ${ }^{108}$.

Staraniem starosty (przy poparciu władz wojewódzkich) powołano komisję, która w połowie września $1926 \mathrm{r}$. dokonała oględzin świątyni, wyceniając prace remontowe na 2,6 tys. zł. Budynek był znacznie zniszczony - wymiany wymagało pokrycie dachu, brakowało części okien, drzwi, podłogi. Ganek przy głównym wejściu przechylił się, zmurszały podwaliny i słupy, na których opierała się cała konstrukcja. Całkowitemu zniszczeniu uległo ogrodzenie wokół cerkwi ${ }^{109}$.

Taki stan był skutkiem niewłaściwego użytkowania w czasie wojny oraz notorycznego dewastowania w kolejnych latach. W korespondencji urzędowej pojawiały się informacje o przechodniach załatwiajacych tu swoje potrzeby fizjologiczne i roztaczających się wokół cuchnących wywiewach. Miało to być też miejsce nocnych schadzek żołnierzy ${ }^{110}$. Działo się tak, choć była to jedyna świątynia prawosławna (a pierwotnie unicka) na opisywanym terenie, która uznawano - w rozumieniu ówczesnej polityki konserwatorskiej - za zabytek budownictwa drewnianego ${ }^{111}$.

Jedyne kroki, które władze lokalne podjęły w celu ochrony cerkwi, polegały na ustawieniu ogrodzenia zabezpieczającego ja przed dalszą profanacja. Przy tym jednak rozważano jej rozbiórkę, gdyż znajdowała się w bezpośrednim sąsiedztwie placu wyznaczonego pod budowę kompleksu gmachów szkolnych $^{112}$. Apele bpa Aleksego i metropolity Dionizego, domagające się

107 Zob. przypis 76, 82. Według wojewody białostockiego w 1923 r. w Augustowie miało mieszkać łącznie 37 osób wyznania prawosławnego, a na terenie powiatu - 385. AAN, MWRiOP, sygn. 1056, UWB do ks. biskupa Aleksego w Grodnie w sprawie delegowania do Augustowa ks. K. Jamołowicza, 27 VII 1923, s. 379.

${ }^{108}$ Ibidem, sygn. 1208, Starostwo powiatowe w Augustowie do UWB w sprawie cerkwi pounickiej w Augustowie, 10 IX 1926, s. 336.

109 Ibidem, Protokół naradczy z oględzin cerkwi pounickiej w Augustowie, 6 X 1926, s. 329.

110 Ibidem, sygn. 1184, UWB do MWRiOP w sprawie odbudowy zrujnowanej cerkwi nad Kanałem w Augustowie, 4 XII 1933, s. 6.

111 APB, UWB, sygn. 148, Spis zabytków województwa białostockiego, [lata trzydzieste $\mathrm{XX}$ w.], k. 2.

112 O grunt, na którym planowano budowę szkoły, z racji, że wcześniej przynależał do unickiej cerkwi Kazańskiej Ikony Matki Bożej, ubiegała się także kuria biskupia w Łomży. AAN, 
wyremontowania świątyni jako rekompensaty za rozebraną cerkiew w rynku, uznano - przez wzgląd na niewielka liczbę wiernych i brak środków - za bezpodstawne ${ }^{113}$. Głos w sprawie zabrali także sami wierni, którzy godzili się na likwidację obiektu i oddanie działki pod budowę szkoły, w zamian proszacc o wyasygnowanie kwoty pozwalającej na wzniesienie niewielkiej drewnianej kaplicy na cmentarzu prawosławnym (w oparciu o kosztorys i projekt przygotowany przez architekta powiatowego). Choć augustowska Rada Miejska przychyliła się do tej propozycji, postawiła warunek niemożliwy do spełnienia - nakazywała bowiem, aby wierni udowodnili swoje prawa do świątyni, która - jak pisano - na prawosławna ,została zamieniona w drodze gwałtu nad wierzeniami religijnemi unitów na tle bezwzględnej walki z jaką rząd rosyjski prowadził z kościołem unickim"114. Ostatecznie po 1937 r. cerkiew rozebrano $^{115}$, a w latach powojennych na jej miejscu założono boisko szkolne.

Z zaprezentowanych losów świątyń prawosławnych wyłania się obraz dwóch kierunków działań, które w dwudziestoletnim okresie polskiej państwowości w stosunku do nich podejmowano. Pierwszy, do którego należałoby zaliczyć decyzje realizowane przez tytułowe władze wojskowe, cywilne, jak i kościelne katolickie, był kierunkiem zdecydowanie dominujacym, zmierzajacym do wykorzystania cerkiewnego mienia do celów innych niż dotychczasowe. W nowych realiach widziano je jako służące polskiej, katolickiej większości, a nie jak przed wojna - uprzywilejowanej, niewielkiej grupie carskich urzędników czy żołnierzy. Poruszając kwestie ich przeznaczenia, nigdy nie posługiwano się świętym wezwaniem obiektu czy choćby określeniem „świątynia”, wskazując najczęściej na lokalizację, nazwę pułku, używając sformułowania „cerkiew”, a częściej „była cerkiew”. Owa „byłość” cerkwi, zaprzestanie funkcjonowania jako miejsce kultu prawosławnego, zostało zresztą zalegalizowane już w pierwszych aktach normatywnych władz polskich z końca 1918 r. ${ }^{116}$ Tak pojęta

MWRiOP, sygn. 1208, Biskup łomżyński do wojewody białostockiego w sprawie gruntów i cerkwi pounickiej w Augustowie, 7 X 1927, s. 347.

${ }^{113}$ Ibidem, Wojewoda białostocki do MWRiOP z wnioskiem o nieuwzględnienie wniosku konsystorza prawosławnego w Grodnie o remont cerkwi w Augustowie, 17 V 1928, s. 359.

${ }^{114}$ Ibidem, Filia parafii prawosławnej w Augustowie do rady miasta Augustowa w sprawie budowy cerkwi na cmentarzu prawosławnym, 7 II 1928, s. 355; ibidem, Starostwo powiatowe w Augustowie do UWB o podaniu prawosławnych do magistratu miasta Augustowa, 14 III 1928, s. 352.

115 Jeszcze w tym roku pisał o niej Mieczysław Orłowicz, twierdząc, że jest to stara cerkiew, bardzo malownicza, lecz ówcześnie opuszczona i chyląca się ku ruinie. M. Orłowicz, Przewodnik ilustrowany po województwie białostockim z ilustracjami, planami i mapami, Białystok 1937, s. 316.

116 Wskazywał na to już Henryk Świątkowski w 1937 r. Zob. H. Świątkowski, Wyznania religijne $w$ Polsce ze szczególnym uwzględnieniem ich stanu prawnego, cz. 1: Wyznania $i$ zwiazki religijne, Warszawa 1937, s. 152. 
desakralizacja nie miała jednak nic wspólnego z przepisami kanonicznymi, a wynikała z powiązania świątyń z byłym systemem politycznym, z grupa wiernych (urzędników, żołnierzy) znienawidzonych w kontekście faktu odzyskania niepodległości. Od władz polskich zależało też, przy których obiektach, w „nowych” warunkach, zaczną działać placówki parafialne, a tym samym którym przywróci się charakter sacrum.

Mimo iż MWRiOP przestrzegało przejemców cerkwi o jedynie tymczasowym użytkowaniu, do chwili ustawowego uregulowania położenia Kościoła prawosławnego w Polsce, w rzeczywistości, godząc się na rozbieranie kopuł i hełmów czy radykalne zmiany we wnętrzach świątyń, kreowało stan faktyczny. Czyniło to świadomie, mając wiedzę o liczbie prawosławnych, która była podstawowym, jeśli nie jedynym, kryterium przyznania Kościołowi prawosławnemu użytkowanego przed wojną mienia. Wieloletni brak rozwiąań prawnych pozwolił też na rozbiórki opustoszałych cerkwi w oparciu o decyzje komisji budowlanych stwierdzających zagrożenie bezpieczeństwa publicznego. Ich zasadność trudno było sprawdzić lub podważyć, gdyż zasiadali w nich najczęściej urzędnicy postulujący jednocześnie likwidację świątyń. Wydaje się też, że samo „zagrożenie bezpieczeństwa” stanowiło termin - w myśl ówczesnych przepisów - bardzo szeroki i dotyczyło na równi drobnych usterek (np. ubytki w pokryciu dachowym), które w konsekwencji mogły doprowadzić do katastrofy budowlanej, jak i realnej groźby zawalenia. Problem ten został uwypuklony w kontekście cerkwi na augustowskim rynku. Zdziwienie budzi też ilustracja przedstawiająca świątynię garnizonową w Łomży, zamieszczona w wydawnictwie poświęconym otwarciu Domu Żołnierza, opatrzona podpisem „Ruiny, z których powstał Dom Żołnierza”, gdyż widać na niej obiekt, którego elewacje i mury zachowały się w co najmniej przyzwoitym stanie ${ }^{117}$.

Brak klarownych przepisów powodował też często spory o to, które z nowych funkcji proponowanych dla cerkwi były najbardziej właściwe i najlepiej odpowiadały zapotrzebowaniu społeczeństwa. Niezależnie od tego należy stwierdzić, że poprzez adaptację na świątynię katolicką czy obiekt świecki odpowiadano na potrzeby większej grupy, niż gdyby cerkiew pozostała w dobrach prawosławnych. Uwidoczniły się tu też problemy ekonomiczne przejemców świątyń, gdyż do prac majacych dostosować szatę architektoniczną czy wnętrza obiektów do nowych funkcji dochodziło dopiero po kilku latach od rozpoczęcia użytkowania. Nie było też mowy o spektakularnych przebudowach, takich jak choćby w Radomiu czy Skierniewicach lub o przebudowach w ogóle, jak również o usuwaniu elementów najbardziej kojarzonych z rosyjskim prawosławiem. Przede wszystkim dotyczyło to cebulastych kopuł i hełmów, przy zachowaniu pierwotnych podziałów elewacji i wnętrza ${ }^{118}$.

${ }^{117}$ Na otwarcie Domu Żotnierza..., s. 12.

118 AAN, MWRiOP, sygn. 1215, MSW do MWRiOP w sprawie cerkwi prawosławnej w Łomży przekazanej katolickim władzom kościelnym, 24 XII 1927, s. 153; APB, UWB, sygn. 287, 
Drugi kierunek działań widzieć należy przez pryzmat prawosławnych władz kościelnych, które całkowicie podporządkowane władzom państwowym utraciły zdecydowaną większość dawnego majątku. Choć na opisywanym terenie powstała parafia prawosławna, a prawosławnym żołnierzom udostępniono cerkiew i kaplicę, zwraca uwagę dążenie do ich izolacji i wyparcia poza centrum miasta, które zajmowali za czasów rosyjskiego panowania. Analogiczne przykłady z innych obszarów Królestwa Polskiego (Kielce, Radom, Włocławek) pokazuja, że wyznaczoną dla nich przestrzenią były przede wszystkim prawosławne nekropolie.

Zadowolenie historyka, jak i historyka architektury może budzić fakt, że znaczna część świątyń, opisana w niniejszym artykule, istnieje do dziś, nadal świadcząc o swoim pierwotnym przeznaczeniu.

\section{Streszczenie}

W artykule skupiono się na szczegółowym przedstawieniu okoliczności, w jakich w okresie międzywojennym, w realiach niepodległej Polski, znalazły się świątynie prawosławne w Suwałkach, Łomży i Augustowie. Głównym celem było określenie polityki, którą prowadziły w stosunku do nich władze wojskowe, cywilne (centralne i samorządowe) oraz kościelne (rzymskokatolickie i prawosławne). Na tej podstawie starano się sprecyzować pewne schematy czy prawidłowości postępowania z cerkiewnym dziedzictwem, charakterystyczne nie tylko dla trzech wybranych miast, ale obszaru całego Królestwa Polskiego. Specyfika świątyń wiązała się z ich fundatorem, grupą wiernych, którym służyły, oraz uprzywilejowaną lokalizacją w przestrzeni urbanistycznej. Poza nielicznymi wyjątkami (cerkwie greckokatolickie, cerkwie dla jednowierców) budowano je bowiem od lat trzydziestych XIX w. z inspiracji władz carskich, z przeznaczeniem dla rosyjskich urzędników i wojska, w szacie architektonicznej właściwej świątyniom wznoszonym na terenie Rosji. Takie uwarunkowania spowodowały, że polska ludność odnosiła się do nich wrogo i utożsamiała je z polityką rusyfikacyjną. W związku z tym po 1915 r., kiedy rosyjski aparat administracyjny i żołnierze wycofali się z Królestwa Polskiego, cerkwie były przeznaczane na katolickie kościoły dla polskich żołnierzy i polskiej ludności cywilnej. Po spełnieniu potrzeb religijnych tych dwóch grup pozostałe cerkwie uległy rozbiórce lub zostały zaadaptowane na obiekty świeckie. Gwałtowne zmniejszenie się liczebności ludności prawosławnej oraz restrykcyjna polityka władz polskich spowodowały, że na interesującym obszarze powołano tylko jedną parafię (dwie cerkwie przekazano też żołnierzom wyznania prawosławnego). Marginalizowane były też apele hierarchów prawosławnych o zwrot czy odszkodowania za odebrane mienie.

Dokumentacja dot. kościoła gimnazjalnego w Suwałkach oraz karta pocztowa z widokiem na kościół przed przebudowa, 1923, k. 1-3; W. Dziewanowski, J. Litewski, Dzieje 1. Putku Ułanów Krechowieckich, Warszawa 1932, wkładka fotograficzna pomiędzy s. 231 i 232; K. Skłodowski, Stużba duszpasterska..., s. 62-63. 


\section{Civil, military and Church authorities and problem of Orthodox churches in the Second Polish Republic - a study illustrated with an example of churches at Suwałki, Łomża and Augustów}

This article describes in great detail the situation of Orthodox Church buildings at Suwałki, Łomża and Augustów, in the interwar period, in the realities of independent Poland. The main purpose was to describe the policy of military, civil (central and self-government) and Church authorities (Roman Catholic and Orthodox) in this respect. Certain patterns of how authorities dealt with the Orthodox heritage characteristic not only of three selected towns, but of the whole Kingdom of Poland are described. The specificity of churches was connected with its founder, group of the faithful that used them their and privileged location in the urban space. Apart from some exceptions (Greek Catholic churches, Edinoverie churches), they were built from the 1830s by the Tsarist authorities for Russian officials and army. For this reason Polish population regarded them with hostility and equated with Russification policy. As a result, after 1915, when Russian administrative apparatus and soldiers left the Kingdom of Poland, Orthodox churches were converted into Catholic churches for Polish soldiers and Polish civil population. After fulfilling religious needs of these two groups, remaining Orthodox Church buildings were demolished or converted into secular objects. Due to a rapid decline in Orthodox population and restrictive policy of the Polish authorities there was only one new parish created in the area (two Orthodox churches were given to Orthodox soldiers). Claims of the Orthodox hierarchy for return or compensation were marginalized.

\section{Bibliografia}

Augustów. Monografia historyczna, red. J. Szlaszyński, A. Makowski, Augustów 2007.

Bendza W., Regulacja kościelnych spraw majatkowych na przykładzie Kościoła prawosławnego $w$ Polsce, Warszawa 2009.

Borowik S., Parafia w Suwatkach, „Przegląd Prawosławny” 2010, nr 9, s. 24-27.

Dobroński A.Cz., Łomża w latach 1866-1918, Łomża-Białystok 1993.

Dziewanowski W., Litewski J., Dzieje 1. Pułku Ułanów Krechowieckich, Warszawa 1932.

Guzewicz W., Duszpasterstwo wojskowe na terenie diecezji łomżyńskiej w latach 1918-1939, „Roczniki Teologiczne” 2001, t. XLVIII, z. 4, s. 161-179.

Jemielity W., Dzieje Łomży tysiacletnie. Zarys historii miasta, Łomża 2005.

Jemielity W., Łomżyński Dziekanat Prawosławny, „Studia Teologiczne” 1996, t. XIV, s. 181-207.

Kęsik J., Naród pod bronia. Społeczeństwo w programie polskiej polityki wojskowej 1918-1939, Wrocław 1998.

Kraśnicka U., Organizacja rzymskokatolickiego duszpasterstwa wojskowego na terenie DOK III Grodno w latach 1921-1939, „Zeszyt Naukowy Muzeum Wojska w Białymstoku” 1998, z. 11 , s. $60-71$.

Matusiewicz A., Światynie w Suwatkach w XIX wieku, „Rocznik Augustowsko-Suwalski” 2012 , t. XII, s. 23-58.

Na otwarcie Domu Żotnierza i dziesięciolecie obrony Łomży 1920-1930, Łomża 1930.

Odziemkowski J., Spychała B., Duszpasterstwo wojskowe w Drugiej Rzeczypospolitej, Warszawa 1987.

Orłowicz M., Przewodnik ilustrowany po województwie białostockim z ilustracjami, planami i mapami, Białystok 1937.

Papierzyńska-Turek M., Między tradycja a rzeczywistościa. Państwo wobec prawostawia 1918-1939, Warszawa 1989. 
Skłodowski K., Infrastruktura oraz „terenowe wyposażenie” garnizonu Suwatki (1922-1939), „Rocznik Augustowsko-Suwalski” 2007, t. VII, s. 35-50.

Skłodowski K., Stużba duszpasterska w garnizonie Suwatki 1921-1939, „Rocznik Augustowsko-Suwalski" 2012, t. XII, s. 59-76.

Sokoł K., Sosna A., Cerkwie w centralnej Polsce 1815-1915, Białystok 2011.

Sosna G., Troc-Sosna A., Hierarchia i kler Kościoła prawosławnego w granicach II Rzeczypospolitej i Polski powojennej w XIX-XXI wieku, Ryboły 2012.

Sosna G., Troc-Sosna A., Zapomniane dziedzictwo. Nie istniejqce już cerkwie $w$ dorzeczu Biebrzy i Narwi, Białystok 2002.

Szlaszyński J., 1. Pułk Ułanów Krechowieckich w Augustowie, „Rocznik Augustowsko-Suwalski” 2006, t. VI, s. 89-114.

Świątkowski H., Wyznania religijne $w$ Polsce ze szczególnym uwzględnieniem ich stanu prawnego, cz. 1: Wyznania i zwiqzki religijne, Warszawa 1937.

Wyjattkowa parafia, krótkie opisanie kościoła i parafii pod wezwaniem Najświętszego Serca Pana Jezusa w Suwatkach, red. J. Bacewicz, Suwałki 2007.

Zubowski P., Cerkwie prawostawne Łodzi i regionu tódzkiego $w$ dwudziestoleciu międzywojennym (1918-1939), Białystok 2014.

Бомбардировка съ аэроплана Лолжинскаго собора, „Варшавскій Епархіалный Листокъ”, 16 IV 1915, № 8, s. 102-103.

Вторичная бомбардировка Ломюинскаго собора нглецкиль аэропланомь, „Варшавскій Епархіалный Листокъ”, 16 V 1915, № 10, s. 130-131.

Кь разборкго православнаго храма въ Августовьь, „Воскресное Чтеніе”, 16 I 1927, № 3, s. 24.

Оскверненія нғлиали православныхь иерквей въ Сувалской губерніи, „Варшавскій Епархіалный Листокъ”, 1 XII 1914, № 23, s. 352-355.

Пріђзжій, Корреспондениіи. Из Августова, „Воскресное Чтеніе”, 12 IX 1926, № 37, s. $586-587$.

Bi o g r a m: Piotr Zubowski - doktorant w Instytucie Historycznym Uniwersytetu Wrocławskiego, pracownik Ośrodka „Pamięć i Przyszłość” we Wrocławiu, członek redakcji „Rocznika Ziem Zachodnich” i „Wrocławskiego Rocznika Historii Mówionej”. Zainteresowania badawcze: historia Europy Środkowo-Wschodniej w XIX-XX w., związki architektury z polityka, historia Wrocławia po $1945 \mathrm{r}$. W ramach pracy doktorskiej prowadzi badania związane z prawosławnym budownictwem sakralnym w II Rzeczypospolitej. E-mail: piotr.j.zubowski@gmail.com. 